\title{
Aerosol indirect effects - general circulation model intercomparison and evaluation with satellite data
}

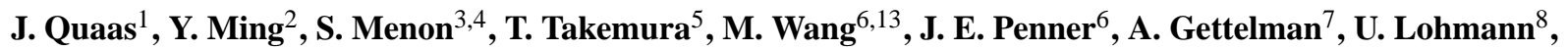 \\ N. Bellouin ${ }^{9}$, O. Boucher ${ }^{9}$, A. M. Sayer ${ }^{10}$, G. E. Thomas $^{10}$, A. McComiskey ${ }^{11}$, G. Feingold ${ }^{11}$, C. Hoose ${ }^{12}$, \\ J. E. Kristjánsson ${ }^{12}$, X. Liu ${ }^{13}$, Y. Balkanski1 ${ }^{14}$, L. J. Donner ${ }^{2}$, P. A. Ginoux ${ }^{2}$, P. Stier ${ }^{10}$, B. Grandey ${ }^{10}$, J. Feichter ${ }^{1}$, \\ I. Sednev ${ }^{3}$, S. E. Bauer ${ }^{4}$, D. Koch ${ }^{4}$, R. G. Grainger ${ }^{10}$, A. Kirkevåg ${ }^{15}$, T. Iversen ${ }^{12,15}$, Ø. Seland ${ }^{15}$, R. Easter $^{13}$, \\ S. J. Ghan ${ }^{13}$, P. J. Rasch ${ }^{13}$, H. Morrison ${ }^{7}$, J.-F. Lamarque ${ }^{7}$, M. J. Iacono ${ }^{16}$, S. Kinne ${ }^{1}$, and M. Schulz ${ }^{14}$ \\ ${ }^{1}$ Max Planck Institute for Meteorology, Hamburg, Germany \\ ${ }^{2}$ Geophysical Fluid Dynamics Laboratory/NOAA, Princeton, USA \\ ${ }^{3}$ Lawrence Berkeley National Laboratory, Berkeley, USA \\ ${ }^{4}$ Goddard Institute for Space Studies/NASA, New York, USA \\ ${ }^{5}$ Kyushu University, Fukoka, Japan \\ ${ }^{6}$ University of Michigan, Ann Arbor, USA \\ ${ }^{7}$ National Center for Atmospheric Research, Boulder, USA \\ ${ }^{8}$ Institute for Atmospheric and Climate Science/ETH Zurich, Switzerland \\ ${ }^{9}$ Met Office Hadley Centre, Exeter, UK \\ ${ }^{10}$ Atmospheric, Oceanic and Planetary Physics, University of Oxford, UK \\ ${ }^{11}$ NOAA Earth System Research Laboratory, Boulder, USA \\ ${ }^{12}$ Department of Geosciences, University of Oslo, Norway \\ ${ }^{13}$ Pacific Northwest National Laboratory, Richland, USA \\ ${ }^{14}$ Laboratoire des Sciences du Climat et de l'Environnement/IPSL, Gif-sur-Yvette, France \\ ${ }^{15}$ Norwegian Meteorological Institute, Oslo, Norway \\ ${ }^{16}$ Atmospheric and Environmental Research, Inc., Lexington, USA
}

Received: 18 May 2009 - Published in Atmos. Chem. Phys. Discuss.: 4 June 2009

Revised: 31 October 2009 - Accepted: 2 November 2009 - Published: 16 November 2009

\begin{abstract}
Aerosol indirect effects continue to constitute one of the most important uncertainties for anthropogenic climate perturbations. Within the international AEROCOM initiative, the representation of aerosol-cloud-radiation interactions in ten different general circulation models (GCMs) is evaluated using three satellite datasets. The focus is on stratiform liquid water clouds since most GCMs do not include ice nucleation effects, and none of the model explicitly parameterises aerosol effects on convective clouds. We compute statistical relationships between aerosol optical depth $\left(\tau_{a}\right)$ and various cloud and radiation quantities in a manner that is consistent between the models and the satellite data. It is found that the model-simulated influence of aerosols on
\end{abstract}

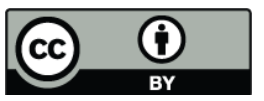

Correspondence to: J. Quaas (johannes.quaas@zmaw.de) cloud droplet number concentration $\left(N_{d}\right)$ compares relatively well to the satellite data at least over the ocean. The relationship between $\tau_{a}$ and liquid water path is simulated much too strongly by the models. This suggests that the implementation of the second aerosol indirect effect mainly in terms of an autoconversion parameterisation has to be revisited in the GCMs. A positive relationship between total cloud fraction $\left(f_{\text {cld }}\right)$ and $\tau_{a}$ as found in the satellite data is simulated by the majority of the models, albeit less strongly than that in the satellite data in most of them. In a discussion of the hypotheses proposed in the literature to explain the satellite-derived strong $f_{\mathrm{cld}}-\tau_{a}$ relationship, our results indicate that none can be identified as a unique explanation. Relationships similar to the ones found in satellite data between $\tau_{a}$ and cloud top temperature or outgoing long-wave radiation (OLR) are simulated by only a few GCMs. The GCMs that simulate a negative OLR $-\tau_{a}$ relationship show a strong positive correlation

Published by Copernicus Publications on behalf of the European Geosciences Union. 
between $\tau_{a}$ and $f_{\text {cld }}$. The short-wave total aerosol radiative forcing as simulated by the GCMs is strongly influenced by the simulated anthropogenic fraction of $\tau_{a}$, and parameterisation assumptions such as a lower bound on $N_{d}$. Nevertheless, the strengths of the statistical relationships are good predictors for the aerosol forcings in the models. An estimate of the total short-wave aerosol forcing inferred from the combination of these predictors for the modelled forcings with the satellite-derived statistical relationships yields a global annual mean value of $-1.5 \pm 0.5 \mathrm{Wm}^{-2}$. In an alternative approach, the radiative flux perturbation due to anthropogenic aerosols can be broken down into a component over the cloud-free portion of the globe (approximately the aerosol direct effect) and a component over the cloudy portion of the globe (approximately the aerosol indirect effect). An estimate obtained by scaling these simulated clearand cloudy-sky forcings with estimates of anthropogenic $\tau_{a}$ and satellite-retrieved $N_{d}-\tau_{a}$ regression slopes, respectively, yields a global, annual-mean aerosol direct effect estimate of $-0.4 \pm 0.2 \mathrm{Wm}^{-2}$ and a cloudy-sky (aerosol indirect effect) estimate of $-0.7 \pm 0.5 \mathrm{Wm}^{-2}$, with a total estimate of $-1.2 \pm 0.4 \mathrm{Wm}^{-2}$.

\section{Introduction}

Anthropogenic aerosols impact the Earth's radiation balance and thus exert a forcing on global climate. Aerosols scatter and may absorb solar radiation resulting in the "aerosol direct effect". Hydrophilic aerosols can serve as cloud condensation nuclei and thus alter cloud properties. An enhanced cloud droplet number concentration $\left(N_{d}\right)$ at constant cloud liquid water path $(L)$ leads to smaller cloud droplet effective radii $\left(r_{e}\right)$ and increased cloud albedo (Twomey, 1974). This process is usually referred to as the "first aerosol indirect effect" or "cloud albedo effect". It has been hypothesised that smaller $r_{e}$ result in a reduced precipitation formation rate and potentially an enhanced liquid water path, cloud lifetime and total cloud fraction $\left(f_{\text {cld }}\right)$. This is referred to as the "second aerosol indirect effect" or "cloud lifetime effect" (Albrecht, 1989) and may also lead to an increased geometrical thickness of clouds (Pincus and Baker, 1994; Brenguier et al., 2000). In convective clouds, the smaller cloud droplets freeze at higher altitudes above cloud base, releasing latent heat higher up in the atmosphere, potentially invigorating updrafts (Devasthale et al., 2005; Koren et al., 2005). This "thermodynamic effect" may be another reason for increased cloud-top heights (decreased cloud-top temperatures), leading to a potentially increased warming cloud greenhouse effect.

In its latest assessment report, the Intergovernmental Panel on Climate Change only quantified the radiative forcing due to the cloud albedo effect (IPCC, 2007). The spread among model-calculated radiative forcings due to this process constitutes the largest uncertainty among the quantified radiative forcings. The IPCC estimated the global annual mean cloud albedo effect to be $-0.7 \mathrm{Wm}^{-2}$ with a 5 to $95 \%$ confidence, or $90 \%$ confidence range between -1.8 and $-0.3 \mathrm{Wm}^{-2}$. According to general circulation model (GCM) estimates, the cloud lifetime effect may be of a similar magnitude (Lohmann and Feichter, 2005; Denman et al., 2007). Recent studies constraining the aerosol indirect effect by satellite observations (Lohmann and Lesins, 2002; Quaas et al., 2006), or estimating it from satellite data (Quaas et al., 2008; cloud albedo effect only), suggest that IPCC (2007) may overestimate the magnitude of the indirect effects.

Satellite data have been used to analyse aerosol-cloud correlations, such as relationships between column aerosol concentrations (measured, e.g. by the aerosol optical depth, $\tau_{a}$ ) and either $r_{e}, N_{d}$ or $L$ (Nakajima et al., 2001; Bréon et al., 2002; Sekiguchi et al., 2003; Quaas et al., 2004; Kaufman et al., 2005; Quaas et al., 2006; Storelvmo et al., 2006a; Menon et al., 2008a). In this study, we use three satellite datasets and ten GCMs and analyse statistical relationships between $\tau_{a}$ and cloud and radiation properties to evaluate the GCM parameterisations.

It has also been shown that cloud fraction is strongly correlated with $\tau_{a}$ (Sekiguchi et al., 2003; Loeb and ManaloSmith, 2005; Kaufman et al., 2005; Kaufman and Koren, 2006; Myhre et al., 2007; Quaas et al., 2008; Menon et al., 2008a). However, it is debated whether this effect is due to the aerosol cloud lifetime effect, or rather due to dynamical influences such as convergence (Mauger and Norris, 2007; Loeb and Schuster, 2008; Stevens and Brenguier, 2009), swelling of aerosols in more humid air surrounding clouds (Haywood et al., 1997; Charlson et al., 2007; Koren et al., 2007; Myhre et al., 2007; Twohy et al., 2009), or satellite retrieval errors such as cloud contamination or 3-D radiation effects (Loeb and Manalo-Smith, 2005; Zhang et al., 2005; Wen et al., 2007; Tian et al., 2008; Várnai and Marshak, 2009). In the present study, the GCM results are used to show that none of these hypotheses is the unique explanation for the $f_{\mathrm{cld}}-\tau_{a}$ relationship found in the satellite data.

This study is conducted in the context of the AEROCOM initiative. Within this initiative, aerosol modules in several of the GCMs examined here have been evaluated using satelliteand ground-based remote sensing data (Kinne et al., 2006), and the simulated aerosol direct radiative forcings have been analysed (Schulz et al., 2006). Concerning aerosol-cloud interactions, some of the GCMs were previously evaluated in single-column mode with in-situ aircraft microphysical measurements (Menon et al., 2003) and, also within the AEROCOM initiative, with various sensitivity studies investigating the reasons for the spread in model-simulated aerosol indirect radiative forcings (Penner et al., 2006). However, it should be noted that the models have evolved and cannot be easily compared to earlier model versions. 


\subsection{Methods}

All data, both for satellite retrievals and model simulation results, are interpolated to a $2.5^{\circ} \times 2.5^{\circ}$ regular longitudelatitude grid. Consistently in both satellite and model data, the various cloud and radiation quantities are correlated to $\tau_{a}$ at daily (i.e. instantaneous values for the polar-orbiting sunsynchronous satellite swath sampling) temporal resolution. The satellite retrievals provide $\tau_{a}$ information only for scenes identified as cloud free, so that in the statistical computations $\tau_{a}$ from the cloud-free scenes is assumed to be representative of the average $\tau_{a}$ within the entire grid-box (as computed in the models). Andreae (2009) found a very high correlation $\left(r^{2}=0.88\right)$ between grid-box average satellite-retrieved $\tau_{a}$ and in-situ-measured cloud-condensation nuclei ( $\mathrm{CCN})$ concentration at cloud base for various polluted and unpolluted situations, a result which supports this assumption.

The satellite data used here are from from the Clouds and the Earth's Radiant Energy System (CERES; Wielicki et al., 1996) for radiation quantities, and from the MODerate Resolution Imaging Spectroradiometer (MODIS) for cloud and aerosol properties, where the MODIS-CERES cloud retrieval (Minnis et al., 2003) and the MODIS Collection 4 aerosol retrieval are used (Remer et al., 2005). Both instruments are on board the Terra and Aqua satellites. The sunsynchronous orbit of the Terra satellite yields data at about 10:30 a.m. local time, and likewise for the Aqua satellite at approximately 01:30 p.m. (equator-crossing times). Data for the Terra satellite cover the March 2000-October 2005 period, and for Aqua, the January 2003-December 2005 period, so that the inter-annual variability is sampled. We analyse the CERES SSF Edition 2 datasets including User Applied Revisions Rev1.

As a third, independent dataset, we use $\tau_{a}$ and cloud properties derived from the Along-Track Scanning Radiometer (ATSR-2) on board the ERS-2 satellite with an equatorcrossing local time of about 10.30 a.m. from the OxfordRAL Aerosols and Clouds (ORAC) Global Retrieval of ATSR Cloud Parameters and Evaluation (GRAPE; version 3; Thomas et al., 2009; Poulsen et al., 2009) for the July 1995June 2000 period.

In the discussion of the results, we will use the MODIS/CERES Terra data as a reference since most studies published so far rely on these data. Part of the influence of the diurnal cycle in cloudiness or aerosol concentration may be inferred to some extent from differences relative to the MODIS Aqua dataset ( 01.30 p.m. overpass time) and some sense for the uncertainty in the retrievals by the difference relative to the ORAC data (10.30 a.m. overpass time). It should be noted that the differences in the three satellite datasets are not able to capture the full observational uncertainty, since all three remote sensing techniques partly rely on similar assumptions.

The model data are sampled at $01.30 \mathrm{p} . \mathrm{m}$. local time (see next paragraph), but it may be noted already at this point that the difference of the models from either satellite data is larger than the one between the Terra and Aqua datasets. The study is limited to liquid water clouds (the cloud phase product from the satellite retrievals is used to sample only liquid clouds), and cloud droplet number concentration is computed from cloud-top droplet effective radius and cloud optical thickness assuming adiabatic clouds (Quaas et al., 2006).

The GCM model simulations were carried out with the atmospheric components only, with imposed observed sea surface temperature (SST) and sea-ice cover distributions. Some of the models (ECHAM5, LMDZ-INCA and SPRINTARS) were nudged to European Centre for Medium-Range Weather Forecasts (ECMWF) Re-Analysis data (ERA-40) for the year 2000; the other models did a climatological five-year simulation (AD 2000-2004) with prescribed SSTs (see Appendix for a description of the individual models and simulations). Greenhouse-gas concentrations and aerosol emissions in the simulations are valid for the year 2000 . For the forcing estimates, a second simulation was carried out with anthropogenic aerosol emissions valid for the year 1750. Aerosol emissions are from the AEROCOM inventory (Dentener et al., 2006). The short-wave total aerosol effect (all effects combined) is diagnosed as a radiative flux perturbation or fixed-SST forcing (Rotstayn and Penner, 2001; Shine et al., 2003; Quaas et al., 2009), where in the case of the nudged simulations the tropospheric profiles also were kept fixed by construction. Model output is sampled daily at 01.30 p.m. local time to match the Aqua equatorial crossing time. Cloud-top quantities are sampled in the uppermost liquid water cloud layer using the cloud overlap hypothesis used in the GCMs to obtain the 2-D field in the same way as seen by the satellite instruments (Quaas et al., 2004). The present study only deals with water clouds. With the exception of ECHAM5, GISS and SPRINTARS, the GCMs do not include parameterisations of aerosol effects on ice nucleation. None of the GCMs explicitly parameterises the effects of aerosols on convective clouds.

Following Feingold et al. (2003), the strength of the aerosol-cloud interactions may be quantified as the relative change in cloud droplet number concentration $\left(N_{d}\right)$ with a relative change in $\tau_{a}$.

In this way, the strength of the aerosol-cloud interaction can be obtained by a linear regression between $\ln N_{d}$ and $\ln \tau_{a}$ We use a similar methodology here to investigate the sensitivity of other cloud and radiation quantities, besides $N_{d}$, to a perturbation in $\tau_{a}$. Please note that for the model evaluation we do not necessarily need to assume a causeeffect relationship behind the aerosol - cloud/radiation correlations. In order to separate to a certain degree different regimes of aerosol types and meteorological situations, the sensitivities are computed separately for fourteen different oceanic and continental regions and for four different seasons (see Fig. 1 for the geographical distribution and Table 1 for an acronym list). For the models, one year (AD 2000) of daily data is used to compute the regressions, while for the 


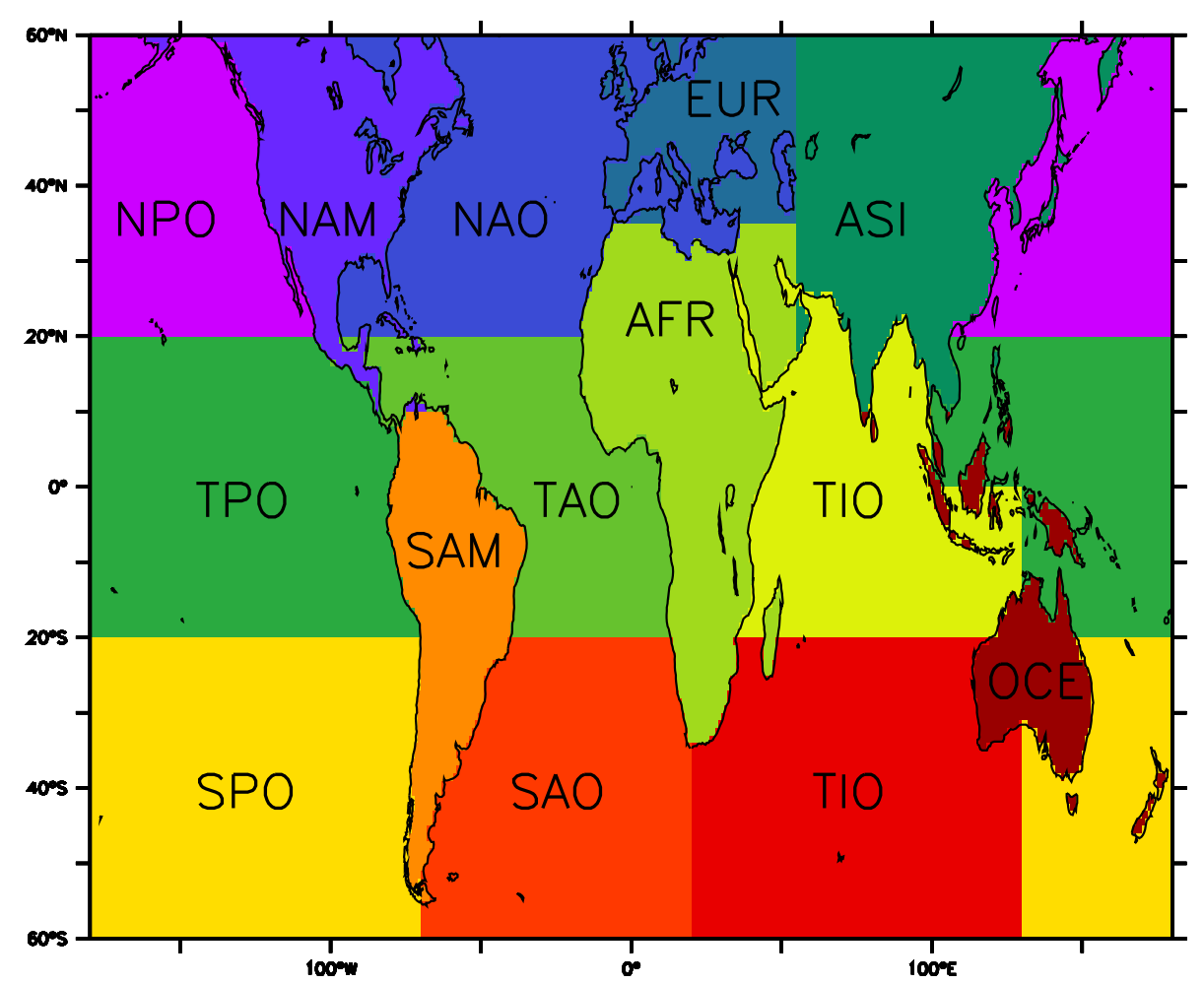

Fig. 1. Definition of the 14 different regions (see Table 1 for acronyms).

Table 1. Acronyms used for the regions and seasons.

\begin{tabular}{ll}
\hline DJF & December-January-February \\
MAM & March-April-May \\
JJA & June-July-August \\
SON & September-October-November \\
NPO & North Pacific Ocean \\
NAM & North America \\
NAO & North Atlantic Ocean \\
EUR & Europe \\
ASI & Asia \\
TPO & Tropical Pacific Ocean \\
TAO & Tropical Atlantic Ocean \\
AFR & Africa \\
TIO & Tropical Indian Ocean \\
SPO & South Pacific Ocean \\
SAM & South America \\
SAO & South Atlantic Ocean \\
SIO & South Indian Ocean \\
OCE & Oceania \\
\hline
\end{tabular}

satellite observations, the sensitivities are computed for each year for which data were available, and the standard deviation of the inter-annual variability of the regression slopes is shown as an error bar.

\subsection{Results}

The mean sensitivities for all seasons in both the land and ocean areas are tabulated and plotted, respectively, in Table 2 and Fig. 2, with the error bars showing the variability among land/ocean regions and seasons. The error bars for the satellite-derived regression slopes also include the inter-annual variability. All individual slopes are shown in supplementary Fig. 1: http://www.atmos-chem-phys.net/9/ 8697/2009/acp-9-8697-2009-supplement.pdf.

\subsubsection{Cloud droplet number concentration}

The most immediate impact of an increase in aerosol concentration on clouds is to increase the cloud droplet number concentration $\left(N_{d}\right)$. As long as the aerosols are hydrophilic, $N_{d}$ would increase with increasing aerosol concentrations. In agreement with previous studies, it is indeed found that in the satellite data, with only very few exceptions, $N_{d}$ and $\tau_{a}$ are positively correlated with statistical significance (Fig. 2a; significance level $>0.99$ for a student-t test). The slope of of the $N_{d}-\tau_{a}$ relationship is about 0.08 and 0.25 over land and oceans, respectively. Comparing the individual regions (supplementary Fig. 1: http://www.atmos-chem-phys. net/9/8697/2009/acp-9-8697-2009-supplement.pdf), no systematic strong seasonal variation is found. Besides the landsea contrast in the relationship, we find a very small, or even negative, relationship over Africa and Oceania, the latter 


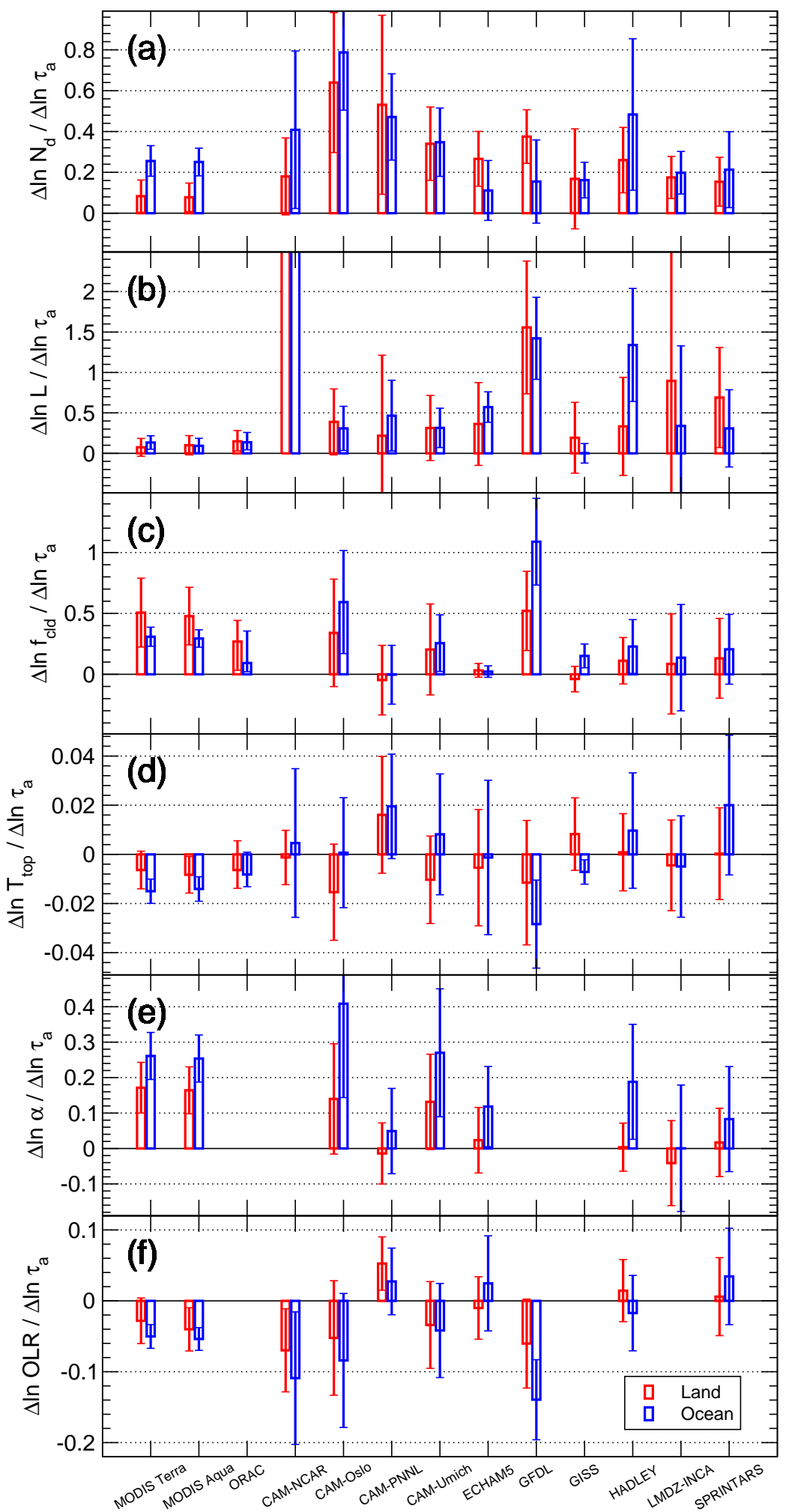

Fig. 2. Sensitivities of (a) $N_{d}$, (b) $L$, (c) $f_{\text {cld }}$, (d) $T_{\text {top }}$, (e) $\alpha$ and ( $f$ ) OLR (defined positive upwards) to $\tau_{a}$ perturbations as obtained from the linear regressions. Results are shown for MODIS (CERES for radiation) on Terra and Aqua, for ATSR-2, and for the ten GCMs as the weighted mean for land (red) and ocean (blue) areas with the error bars showing the standard deviations of the slopes for the land/ocean areas and the four seasons. The data are also listed in Table 2. 
Table 2. Global (land/ocean) annual mean relationship slopes, computed as linear regression between the logarithm of cloud droplet number concentration $\left(N_{d}\right)$, liquid water path $(L)$, total cloud cover $\left(f_{\text {cld }}\right)$, cloud-top temperature $\left(T_{\text {top }}\right)$, planetary albedo $(\alpha)$, and outgoing longwave radiation (OLR) with the logarithm of aerosol optical depth $\left(\tau_{a}\right)$. The land/ocean mean annual mean numbers are given as weighted mean of slopes for all seasons and land/ocean regions. Bold numbers show agreement with the Terra data to within $\pm 25 \%$, gray, underestimation by up to a factor of two, blue, stronger underestimation, green, overestimation by up to a factor of two, red, stronger overestimation compared to the Terra data. The data are plotted in Fig. 2. Gaps indicate that a particular satellite or model did not report all quantities.

\begin{tabular}{|c|c|c|c|c|c|c|c|c|c|c|c|c|c|c|}
\hline Relationship & & Terra & Aqua & ORAC & $\begin{array}{l}\text { CAM- } \\
\text { NCAR }\end{array}$ & $\begin{array}{r}\text { CAM- } \\
\text { Oslo }\end{array}$ & $\begin{array}{l}\text { CAM- } \\
\text { PNNL }\end{array}$ & $\begin{array}{l}\text { CAM- } \\
\text { Umich }\end{array}$ & ECHAM5 & GFDL & GISS & HADLEY & $\begin{array}{r}\text { LMDZ- } \\
\text { INCA }\end{array}$ & $\begin{array}{r}\text { SPRIN- } \\
\text { TARS }\end{array}$ \\
\hline \multirow[t]{2}{*}{$N_{d}-\tau_{a}$} & land & 0.083 & 0.078 & & 0.180 & 0.640 & 0.531 & 0.340 & 0.266 & 0.375 & 0.168 & 0.260 & 0.175 & 0.154 \\
\hline & ocean & 0.256 & 0.251 & & 0.408 & 0.787 & 0.471 & 0.348 & 0.111 & 0.155 & 0.162 & 0.483 & 0.198 & 0.213 \\
\hline \multirow[t]{2}{*}{$L-\tau_{a}$} & land & 0.074 & 0.100 & 0.148 & 3.064 & 0.389 & 0.218 & 0.313 & 0.363 & 1.557 & 0.192 & 0.333 & 0.896 & 0.690 \\
\hline & ocean & 0.134 & 0.093 & 0.136 & 3.615 & 0.309 & 0.466 & 0.315 & 0.572 & 1.422 & 0.000 & 1.340 & 0.339 & 0.308 \\
\hline \multirow[t]{2}{*}{$f_{\mathrm{cld}}-\tau_{a}$} & land & 0.51 & 0.48 & 0.27 & & 0.34 & -0.05 & 0.20 & 0.11 & 0.52 & -0.04 & 0.11 & 0.09 & 0.13 \\
\hline & ocean & 0.31 & 0.29 & 0.09 & & 0.59 & -0.00 & 0.26 & 0.00 & 1.09 & 0.15 & 0.23 & 0.14 & 0.21 \\
\hline \multirow[t]{2}{*}{$T_{\text {top }}-\tau_{a}$} & land & -0.0064 & -0.0083 & -0.0064 & -0.0013 & -0.0154 & 0.0161 & -0.0103 & -0.0054 & -0.0116 & 0.0083 & 0.0009 & -0.0044 & 0.0003 \\
\hline & ocean & -0.0150 & -0.0141 & -0.0082 & 0.0046 & 0.0007 & 0.0195 & 0.0082 & -0.0013 & -0.0284 & -0.0072 & 0.0097 & -0.0049 & 0.0200 \\
\hline \multirow[t]{2}{*}{$\alpha-\tau_{a}$} & land & 0.17 & 0.16 & & & 0.14 & -0.01 & 0.13 & 0.02 & & & 0.00 & -0.04 & 0.02 \\
\hline & ocean & 0.26 & 0.25 & & & 0.41 & 0.05 & 0.27 & 0.12 & & & 0.19 & 0.00 & 0.08 \\
\hline \multirow[t]{2}{*}{$\mathrm{OLR}-\tau_{a}$} & land & -0.028 & -0.040 & & -0.070 & -0.052 & 0.053 & -0.034 & -0.010 & -0.060 & & 0.014 & & 0.006 \\
\hline & ocean & -0.050 & -0.054 & & -0.109 & -0.084 & 0.027 & -0.042 & 0.025 & -0.140 & & -0.017 & & 0.034 \\
\hline
\end{tabular}

including Australia. In these two regions, $\tau_{a}$ is for most seasons dominated by desert dust which hardly acts as $\mathrm{CCN}$ in the arid desert regions. All GCMs overestimate the relationship over land, most of them (nine out of ten) by more than a factor of two. Over oceans, on the other hand, half of the models overestimate, and the other half underestimate the relationship. Most (eight) models fall within a factor of two of the satellite-derived relationship. Six of the models show the correct land-sea contrast. However, in the models, the landsea contrast is much weaker than the factor of three found in the satellite data. Note that the MODIS retrieval algorithms for $\tau_{a}$ are different over land and ocean, which might introduce a bias in the observationally based relationship. The particularity of the dust-dominated Africa and Oceania regions is well reproduced in some of the models (supplementary Fig. 1: http://www.atmos-chem-phys.net/9/8697/2009/ acp-9-8697-2009-supplement.pdf).

The slope of the $N_{d}-\tau_{a}$ relationship is dependent on the spatial scale of the data from which the relationship is computed. It is found that slopes are generally smaller when the data are averaged over larger spatial domains (Sekiguchi et al., 2003; McComiskey et al., 2009). In particular, in situ aircraft measurements observing $\mathrm{CCN}$ and $N_{d}$ in the cores of boundary-layer clouds typically show larger sensitivities than satellite retrievals (McComiskey and Feingold, 2008). The reasons for the reduction of the slope when averaging over cloud ensembles are the variability in liquid water path, updraft velocity, and aerosol concentrations. At larger scales, aerosol and cloud fields may become increasingly uncorrelated, and collision/coalescence of droplets may reduce droplet number concentration just due to liquid water rather than aerosol fluctuations (Feingold, 2003; McComiskey et al., 2009). It is thus important to analyse relationships for models and data at the same scales. The sensitivity also depends on the parameter used to quantify aerosol concentration, with $\tau_{a}$ as used here leading to smaller slopes than other metrics such as the aerosol index (McComiskey et al., 2009). For the $N_{d}$-aerosol relationship, one summer season (June-July-August-September) of ground-based measurements, presumably of superior accuracy compared to the satellite data, has been analysed by McComiskey et al. (2009) from measurements at the Pt. Reyes station on the coast of California where marine stratocumulus are the predominant cloud type. They find a value of 0.30 for the relationship slope of $N_{d}$ vs. total aerosol light scattering (a measure of the vertically integrated total aerosol concentration relatively similar to $\tau_{a}$ diagnosed from the satellite data and the GCMs). McComiskey et al. (2009) investigated the sensitivity of the slope when other quantities are used to specify the aerosol concentrations. Among the ones investigated, total light scattering (which can be considered similar to $\tau_{a}$ ) is the one for which the smallest sensitivity is obtained, since the other measures focus more on the accumulation-mode aerosols which are potentially better suited to serve as $\mathrm{CCN}$. The range McComiskey et al. (2009) obtain is 0.30-0.52. For the satellite retrievals and for the GCMs, we compute the correlation between $N_{d}$ and $\tau_{a}$ for the summer months for the region containing the $\mathrm{Pt}$. Reyes station which we define here as the marine area $130^{\circ} \mathrm{W}-118^{\circ} \mathrm{W}$ and $33^{\circ} \mathrm{N}-45^{\circ} \mathrm{N}$. The results are shown in Fig. 3. It is found that the satellite-derived relationships are close to the ground-based ones, with values of 0.31 and 0.23 for MODIS on Terra and Aqua, respectively. Most models (seven out of nine) simulate a slope that is smaller than the value found by McComiskey et al. (2009), four of which are within a factor of two. Two models, on the other hand, simulate a relationship in this region that is much stronger than the observation-derived ones. The degree to which the measurements at Pt. Reyes are representative can 


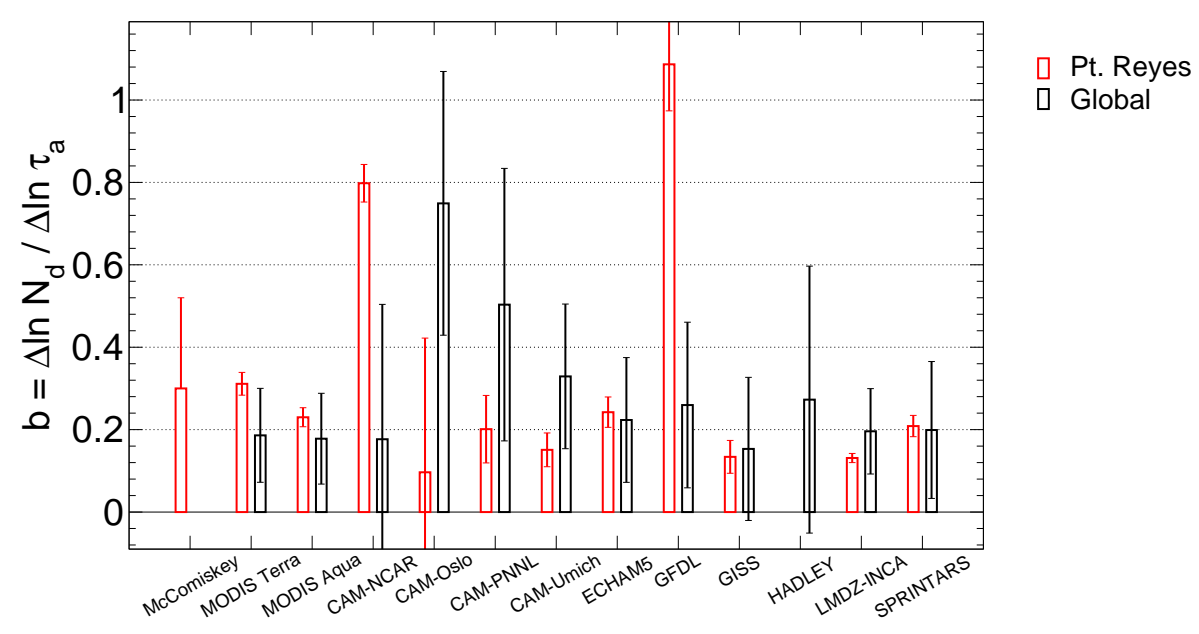

Fig. 3. Sensitivity of $N_{d}$ to $\tau_{a}$ at the Pt. Reyes (California) site in the June-July-August-September season (red) and globally-annually averaged (black). The surface-based remote sensing observations refer to McComiskey et al. (2009) and use the total aerosol light scattering rather than $\tau_{a}$ as a measure for vertically integrated aerosol concentration. The error bar for the surface-based estimate refers to the values obtained for different metrics to quantify aerosol concentrations.

be investigated from the global datasets (Fig. 3). According to the satellite data, the correlation at the global scale is similar to, but slightly smaller, than the one at Pt. Reyes. Two of the four models that simulate a $N_{d}-\tau_{a}$ relationship for Pt. Reyes that is similar to the observations also show a slightly smaller globally averaged relationship compared to the regional one (ECHAM5 and SPRINTARS), while the two others (CAM-PNNL and CAM-Umich) indicate a stronger global-scale relationship.

\subsubsection{Cloud liquid water path}

Due to second aerosol indirect effects, aerosols are assumed to impact cloud lifetime and cloud liquid water path $(L)$. The acting mechanisms are manifold and include precipitation microphysics, cloud dynamics (entrainment), and boundary layer dynamics. As implemented in most GCMs, an increase in $N_{d}$ leads to a decrease in the autoconversion rate, delaying precipitation formation, thus increasing cloud lifetime and cloud liquid water path (Albrecht, 1989). On the other hand, enhanced entrainment of dry air at cloud tops or increased below-cloud evaporation of smaller precipitation drops for clouds with more and smaller cloud droplets has been demonstrated by large-eddy simulations or conceptual models to potentially lead to a decrease in $L$ (Ackerman et al., 2004; Guo et al., 2007; Wood, 2007; Lee et al., 2009a).

We find here that in the majority of cases $L$ is significantly positively correlated with $\tau_{a}$ (Fig. $2 \mathrm{~b}$ and supplementary Fig. 1: http://www.atmos-chem-phys.net/9/8697/ 2009/acp-9-8697-2009-supplement.pdf). The MODIS instruments, on both the Terra and Aqua satellites, as well as the ATSR-2 data show a consistent relationship of similar magnitude over oceans and land.
All models overestimate this relationship by more than a factor of two over land, and all but one equally so over the oceans. The overestimated strength of the simulated $L-\tau_{a}$ relationship can partly be explained by the autoconversion parameterisation. The parameterisations usually describe the dependency of the autoconversion rate on $N_{d}$ as a power law, with the exponent varying between -1.79 and 0 among the models investigated. This exponent is correlated to the $L-\tau_{a}$ relationship slope (Fig. 4) with a correlation coefficient of -0.41 over land and -0.43 over ocean, respectively. Autoconversion rate may also depend on $N_{d}$ implicitly though the threshold at which autoconversion starts, which is often formulated in terms of critical radius (e.g. Rotstayn and Liu, 2005). However, other effects also play a role. It is remarkable that a strongly positive relationship between $\tau_{a}$ and $L$ is found even in the LMDZ-INCA model, in which the autoconversion does not depend on $N_{d}$. Nonmicrophysical reasons for a positive relationship between $L$ and $\tau_{a}$ could be similar to the ones discussed below for the $f_{\text {cld }}-\tau_{a}$ relationship, such as large $L$ in humid regions, where also $\tau_{a}$ is large. Nevertheless, the results shown in Fig. 4 may imply that the simple implementation of the second aerosol indirect effect in terms of an autoconversion parameterisation has to be revisited in the GCMs. The inclusion of counteracting effects by cloud-top entrainment and boundary layer dynamics may constitute an important step in the right direction as might adding a parameterisation that is more able to account for the spectral variation in droplet size as well as supersaturation (Lee et al., 2009b). It is interesting to note that some of the models are able to reproduce the smaller, or even negative, relationships in the tropical regions compared to the extra-tropical regions 
Table 3. Global annual mean forcings and forcing efficiencies. The cloudy-sky forcing is computed from the simulated monthly-mean all-sky forcing, clear-sky forcing (computed for a reference atmosphere without clouds), and cloud fraction. Forcing efficiency is defined as the ratio between global-annual-mean forcing and anthropogenic $\tau_{a}$. Clear-sky forcing is weighted by the clear-sky fraction, and cloudy-sky forcing, by the cloudy-sky fraction, respectively, so that both sum up to the all-sky forcing. Also listed are the global annual mean long-wave aerosol effect and change in $f_{\text {cld }}$ between the present-day (PD) and pre-industrial simulations. For comparison with previous studies (Schulz et al., 2006), also the clear sky forcing and clear-sky forcing efficiencies assuming entirely clear grid-boxes are given.

\begin{tabular}{|c|c|c|c|c|c|c|c|c|c|c|c|}
\hline & Mean & $\begin{array}{l}\text { CAM- } \\
\text { NCAR }\end{array}$ & $\begin{array}{l}\text { CAM- } \\
\text { Oslo }\end{array}$ & $\begin{array}{l}\text { CAM- } \\
\text { PNNL }\end{array}$ & $\begin{array}{l}\text { CAM- } \\
\text { Umich }\end{array}$ & ECHAM5 & GFDL & GISS & HADLEY & $\begin{array}{l}\text { LMDZ- } \\
\text { INCA }\end{array}$ & $\begin{array}{r}\text { SPRIN- } \\
\text { TARS }\end{array}$ \\
\hline All-sky Forcing [W m ${ }^{-2}$ ] & $-1.57 \pm 0.66$ & -2.56 & -1.89 & -2.14 & -1.95 & -1.30 & -2.15 & -0.61 & -1.52 & -0.50 & -1.04 \\
\hline Cloud fraction & $0.55 \pm 0.06$ & & 0.60 & 0.50 & 0.59 & 0.61 & 0.50 & 0.58 & 0.53 & 0.43 & 0.60 \\
\hline Clear-sky forcing $\left[\mathrm{W} \mathrm{m}^{-2}\right]$ & $-0.30 \pm 0.22$ & & -0.06 & -0.27 & -0.42 & -0.28 & -0.83 & -0.02 & -0.40 & -0.23 & -0.22 \\
\hline Cloudy-sky forcing $\left[\mathrm{W} \mathrm{m}^{-2}\right.$ ] & $-1.15 \pm 0.51$ & & -1.83 & -1.87 & -1.53 & -1.01 & -1.32 & -0.59 & -1.13 & -0.27 & -0.82 \\
\hline Anthropogenic $\tau_{a}$ & $0.044 \pm 0.022$ & 0.082 & 0.037 & 0.020 & 0.033 & 0.040 & 0.087 & 0.033 & 0.030 & 0.055 & 0.022 \\
\hline All-sky Forcing efficiency $\left[\mathrm{W} \mathrm{m}^{-2} \tau_{a}^{-1}\right]$ & $-43.11 \pm 26.27$ & -31.37 & -51.01 & -107.5 & -59.33 & -32.01 & -24.58 & -18.51 & -50.05 & -9.14 & -47.62 \\
\hline Clear-sky forcing efficiency [W m $\left.{ }^{-2} \tau_{a}^{-1}\right]$ & $-8.02 \pm 4.69$ & & -1.57 & -13.56 & -12.82 & -7.00 & -9.51 & -0.56 & -13.01 & -4.14 & -10.02 \\
\hline Cloudy-sky forcing efficiency [ $\left.\mathrm{W} \mathrm{m}^{-2} \tau_{a}^{-1}\right]$ & $-36.39 \pm 24.71$ & & -49.44 & -93.94 & -46.51 & -25.00 & -15.08 & -17.95 & -37.04 & -5.00 & -37.59 \\
\hline Longwave aerosol effect $\left[\mathrm{W} \mathrm{m}^{-2}\right]$ & $+0.14 \pm 0.23$ & +0.43 & -0.16 & +0.45 & +0.19 & +0.39 & +0.33 & +0.18 & +0.08 & +0.05 & +0.05 \\
\hline Change in $f_{\text {cld }}(\mathrm{PD}-\mathrm{PI})[\%]$ & $+0.19 \pm 0.28$ & +0.43 & -0.17 & & -0.08 & +0.77 & +0.20 & +0.08 & +0.15 & & +0.12 \\
\hline $\begin{array}{l}\text { Clear-sky forcing assuming entirely clear } \\
\text { grid-boxes }\left[\mathrm{W} \mathrm{m}^{-2}\right]\end{array}$ & $-0.82 \pm 0.62$ & -2.14 & -0.17 & -0.53 & -1.01 & -0.68 & -1.76 & -0.09 & -0.73 & -0.61 & -0.51 \\
\hline $\begin{array}{l}\text { Clear-sky forcing efficiency assuming } \\
\text { entirely clear grid-boxes }\left[\mathrm{W} \mathrm{m}^{-2}\right]\end{array}$ & $-13.40 \pm 15.80$ & 26.10 & -4.66 & -26.79 & -30.71 & -16.87 & -20.11 & -2.78 & -23.86 & -11.10 & -23.26 \\
\hline
\end{tabular}

(supplementary Fig. 1: http://www.atmos-chem-phys.net/9/ 8697/2009/acp-9-8697-2009-supplement.pdf). A reason for this could be that clouds in the tropics can reach high altitudes but still consist of liquid water at their top. Thus, a large absolute variability may be found which perturbs the statistical analysis in such a way that the relatively small aerosol effects cannot be isolated. Also, the scavenging of aerosols by convective precipitating clouds may play an important role in the tropical regions. Aerosols might stabilise the atmosphere though radiative cooling of the surface, reducing convective activity and thus liquid water path. In addition to these process-level interactions, large-scale circulation changes in response to colder surface temperatures due to cooling aerosol forcings might lead to a mean increase in liquid water path (Jones et al., 2007; Koch et al., 2009) More process-oriented research is needed (e.g. following the approach by Suzuki and Stephens, 2008) to investigate the implementation of the second aerosol indirect effect in more detail.

\subsubsection{Cloud fraction}

Satellite data show a strong correlation between total cloud fraction $\left(f_{c l d}\right)$ and $\tau_{a}$, which remains controversial. We find that the ATSR-2 data show a weaker positive correlation than the MODIS data. However, negative correlations are found only in very few regions. The models also show mostly positive relationships between $f_{\mathrm{cld}}$ and $\tau_{a}$, though in most cases not as strong and with more variability (Fig. 2c and supplementary Fig. 1: http://www.atmos-chem-phys.net/9/ 8697/2009/acp-9-8697-2009-supplement.pdf). All models but one show a stronger relationship over ocean than over

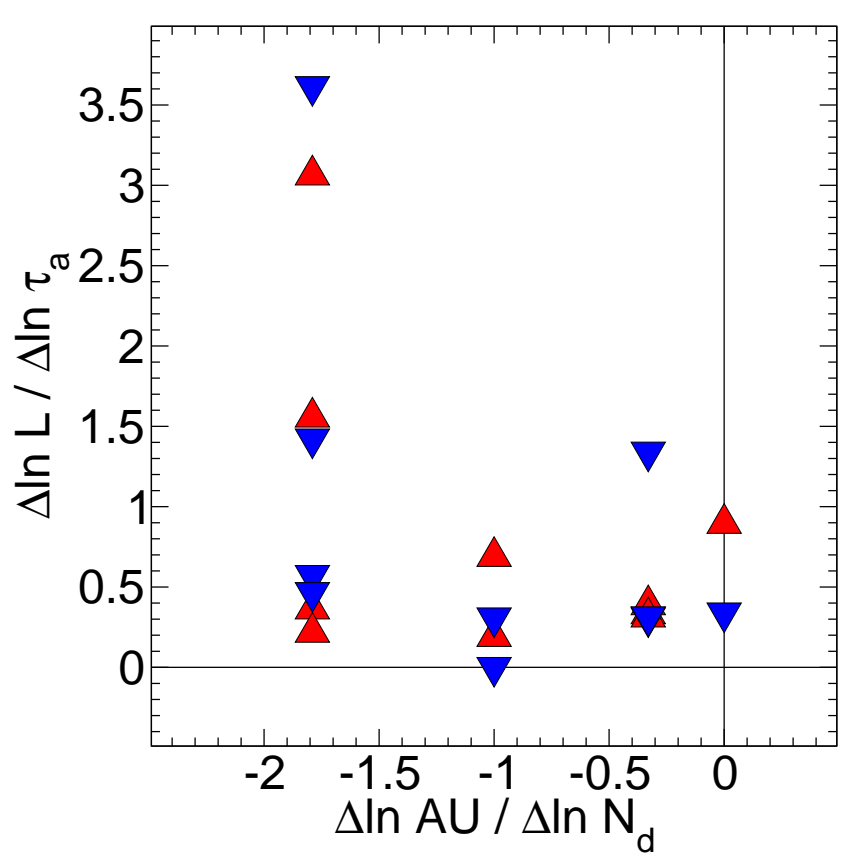

Fig. 4. Dependence of the $L-\tau_{a}$ relationship on the parameterisation of the autoconversion (AU) in the models over land (red) and oceans (blue). In CAM-NCAR, CAM-PNNL, ECHAM5 and GFDL, AU depends on $N_{d}^{-1.79}$ (Khairoutdinov and Kogan, 2000), in GISS and SPRINTARS, on $N_{d}^{-1}$ (Rotstayn and Liu, 2005; Takemura et al., 2005), and in CAM-Oslo, CAM-Umich and Hadley, on $N_{d}^{-0.33}$ (Rasch and Kristjansson, 1998; Jones et al., 2001). In LMDZ-INCA, autoconversion is independent of $N_{d}$. The results for Hadley and CAM-Umich over land are co-incident. 
land, in contrast to the finding in all satellite retrievals. A strong positive relationship is found for most regions in the CAM-Oslo, CAM-Umich and GFDL models.

In the literature, mainly four hypotheses have been discussed as potential reasons for the strongly positive relationship between $\tau_{a}$ and $f_{\text {cld }}$ found in the satellite data. Firstly, the cloud lifetime effect would explain such a correlation through microphysical processes in which increased aerosol concentrations would cause an increase in cloud lifetime and $f_{\text {cld }}$. The GCMs do include some parameterisation of this effect, though relatively crudely as discussed above. Also, while the implementation of the cloud lifetime effect may impact cloud water mixing ratio, which is a prognostic variable in all models, this is only indirectly the case for most models, because cloud fraction is in most of them a diagnostic rather than prognostic variable. Otherwise, the cloud lifetime effect would have a much stronger effect on cloud fraction (Lohmann and Feichter, 1997). It is interesting to note that the GFDL model, which includes a prognostic cloud cover variable (Tiedtke, 1993), is one of the models with a particularly strong $f_{\mathrm{cld}}-\tau_{a}$ relationship. However, we are unable to establish a solid cause-effect relationship without further sensitivity runs. Overall, the majority of the models (six out of eight) indeed show an increase in $f_{\text {cld }}$ from pre-industrial to present-day aerosol concentrations (Table 3) suggesting an aerosol effect on cloud fraction (second aerosol indirect effect). Secondly, a co-variance due to meteorological dynamics such as large-scale convergence might explain the correlation. It is expected that GCMs simulate such a co-variance since the large-scale dynamics are resolved. GCMs for which the simulations are nudged to the re-analysis data (ECHAM5, LMDZ-INCA and SPRINTARS) and thus, dynamics close to the real world, in particular would show such a relationship in the same way as the observations do. The fact that the $f_{\text {cld }}-\tau_{a}$ relationship simulated by these models is weaker than the one shown in the satellite retrievals might imply that large-scale meteorology is not the main factor. Thirdly, due to humidity swelling, $\tau_{a}$ might increase in the vicinity of clouds where the relative humidity is larger without an increase in aerosol number concentrations. GCMs include a parameterisation of this effect and use the prognostic relative humidity to compute $\tau_{a}$. However, effect of relative humidity on $\tau_{a}$ is strongly non-linear and thus the use of clear-sky average relative humidity might low-bias $\tau_{a}$ in partly cloudy grid-boxes. Thus, part of the discrepancy between simulated and retrieved $f_{\text {cld }}-\tau_{a}$ relationship strengths might be due to a deficiency in this parameterisation. Finally, there might be biases in the satellite retrievals with side-scattering of sunlight at cloud edges (3-D effects) or cloud-contamination of pixels labelled as clear-sky, potentially increasing the satellite-retrieved $\tau_{a}$ where clouds are present. Even though this effect operates in the vicinity of clouds, it is likely to persist to some extent when performing statistics at the larger scale as it is done here. The fact that the ATSR-2 retrievals at a higher spatial resolution than MODIS $\left(3 \times 4 \mathrm{~km}^{2}\right.$ compared to $\left.5 \times 5 \mathrm{~km}^{2}\right)$ show a weaker correlation might be an indication that 3-D effects or cloud contamination do play a role. On the other hand, since the GCMs do not simulate 3-D effects and nevertheless show positive $\tau_{a}-f_{\text {cld }}$ relationships, this effect cannot entirely explain the correlation. In conclusion, our results do not allow to identify one of these four hypotheses as a unique explanation for the strong relationship between $\tau_{a}$ and $f_{\text {cld }}$, nor can any of them be clearly excluded. More detailed sensitivity studies, and/or detailed evaluation of satellite-derived relationships with ground-based remote sensing or aircraft observations are needed for a clearer distinction of the processes relevant for the relationship between $\tau_{a}$ and $f_{\text {cld }}$.

\subsubsection{Cloud top temperature}

Confirming earlier studies, we find a negative correlation between cloud top temperature $\left(T_{\text {top }}\right)$ and $\tau_{a}$ consistently in the three satellite datasets (Fig. 2d). The GCMs show a very mixed picture of this effect, with only three models showing on average a negative correlation over both land and ocean, and only one (GFDL) showing this consistently for most regions and seasons (supplementary Fig. 1: http://www.atmos-chem-phys.net/9/8697/ 2009/acp-9-8697-2009-supplement.pdf). We suspect that this behavior involves a complex interplay among convection, boundary layer and large-scale cloud parameterizations in the GFDL model. Further studies are planned to untangle them in a systematic fashion. As discussed for the $f_{\mathrm{cld}}-\tau_{a}$ relationship, co-variation of $\tau_{a}$ and $T_{\text {top }}$ due to large-scale meteorology might be ruled out as a primary reason for the correlation found in the satellite data, since such an effect should also be reflected in the model-simulated relationships at least for the models nudged to re-analysis meteorology. It should be noted that the microphysical effects that would lead to invigorated updrafts in convective clouds are not included in any of the GCMs. Future sensitivity studies with models including such effects might help to better understand the causes for the correlation found in the satellite retrievals.

\subsubsection{Planetary albedo}

As shown above, aerosols have an impact on cloud properties. For climate impacts, ultimately, the influence on the top-of-the-atmosphere (TOA) radiation balance is important. Most aerosol indirect effects mainly impact the solar spectrum, thus changing the short-wave planetary albedo $(\alpha)$. Satellite data show that $\alpha$ is indeed positively correlated with $\tau_{a}$ (Fig. 2e), with a stronger effect over oceans than over land. The $\alpha-\tau_{a}$ relationship is a convolution of co-variation between surface albedo and $\tau_{a}$, clear-sky albedo increase with increasing $\tau_{a}$, and correlation of $\tau_{a}$ with cloud fraction, $L$, and $N_{d}$. Over land, the high surface albedo of snowcovered high-latitude remote areas in the winter season often coincides with low aerosol concentrations. Also, absorbing 
aerosols reduce planetary albedo over bright surfaces. Both effects lead to a negative clear-sky-albedo $-\tau_{a}$ relationship in these cases, implying also a relatively small all-sky albedo $-\tau_{a}$ relationship. Aerosol retrievals in such areas of high surface albedo are not possible for the satellite products we use, and the exclusion of these cases leads to a high-bias in the satellite-derived $\alpha-\tau_{a}$ relationships in high latitude land areas in winter. In terms of radiation, this bias is less strong, since incident solar radiation in high latitude winter is small. Thus, somewhat smaller slopes of the $\alpha-\tau_{a}$ relationship in the models compared to the satellite data are expected over land.

Overall, the models (except for two models over land) also show a positive correlation, and all models show the same land-sea contrast with stronger relationships over ocean than over land. However, the relationship for most models (five out of seven) is weaker than in the observations, with two (CAM-Oslo and CAM-Umich) models simulating relationships very close to the satellite retrievals. Variability in $\alpha$ is presumably most sensitive to changes in $f_{\text {cld }}$. This explains why the models closest to the observations for the $f_{\text {cld }}-\tau_{a}$ relationship simulate the best (strongest) $\alpha-\tau_{a}$ relationships.

\subsubsection{Outgoing long-wave radiation}

From the satellite retrievals, we find that the outgoing longwave radiation (OLR, defined positive upwards) is negatively correlated with $\tau_{a}$ (Fig. 2f), consistently for most regions and seasons (with only four to five exceptions, supplementary Fig. 1: http://www.atmos-chem-phys.net/9/8697/2009/ acp-9-8697-2009-supplement.pdf). Likely reasons for this are the positive relationship between $f_{\text {cld }}$ and $\tau_{a}$, and the negative relationship between $T_{\text {top }}$ and $\tau_{a}$. A positive relationship between $L$ and $\tau_{a}$, and surface cooling due to aerosol forcing would also lead to a negative OLR $-\tau_{a}$ relationship, and aerosol absorption may play a role. Only four out of eight models also show a negative relationship for both land and ocean, all of which agree with the satellite retrievals that the relationship is stronger over oceans than over land. A very strong OLR $-\tau_{a}$ relationship is found for the GFDL model, which shows both a strongly positive $f_{\mathrm{cld}}-\tau_{a}$ and a strongly negative $T_{\text {top }}-\tau_{a}$ relationship. It might be speculated that the skill of the GFDL model is related to the Donner (1993) convection scheme parameterising a spectrum of updroughts and thus a better representation of mid-level clouds originating from convective detrainment. The negative OLR $-\tau_{a}$ relationship found for CAM-Oslo and CAMUmich, on the other hand, is probably mainly due to the strong positive relationships these models show between $f_{\text {cld }}$ and $\tau_{a}$. As shown in Table 3, most models (nine out of ten) show a decrease in OLR from pre-industrial to present-day aerosol concentrations, implying a small long-wave warming aerosol effect of about $+0.14 \mathrm{Wm}^{-2}$.

\subsubsection{Radiative forcing}

Table 3 lists the short-wave radiative forcing (computed as a radiative flux perturbation) due to anthropogenic aerosols as computed by the GCMs along with a (highly uncertain) estimate from satellite data. The total (direct + all indirect) shortwave aerosol forcing is analysed here. A breakdown into individual forcing processes is possible only very coarsely in the approach taken here simulating aerosols and cloud microphysics interactively in the GCMs. Global annual mean values of the forcing split into clear- and cloudy-sky components are given in Table 3, where the clear and cloudy forcings are weighted by the clear- and cloudy-sky fractions and add up to the all-sky forcing. According to the models, the forcing $\left(-1.6 \mathrm{Wm}^{-2}\right.$ on average) is dominated by cloud-sky forcing ( $80 \%$ of the all-sky forcing), implying that the indirect effects are more important than the direct effect. The estimated all-sky shortwave forcing varies by a factor of five among the models, and large inter-model variability is found for both clear and cloudy-sky estimates. In addition, the forcing efficiencies, i.e. the forcings normalised by the global-annual-mean anthropogenic $\tau_{a}$, show a very large inter-model spread with variations of more than a factor of ten.

Besides these differences in the representation of aerosol direct and indirect effects in the models, a first-order influence on the forcing is the anthropogenic perturbation of $\tau_{a}$ (Fig. 5). This varies strongly, by a factor of four, among the models, despite the fact that all models use the same emissions (Textor et al., 2007). For clear-sky situations, the forcing is dominated by the anthropogenic $\tau_{a}$, while for the allsky forcing, other factors also play a large role (see below). Imposing a lower limit to $N_{d}$ as done in many models limits the radiative forcing by the aerosol indirect effects as investigated by Hoose et al. (2009) and also demonstrated in earlier studies (Lohmann et al., 2000; Ghan et al., 2001; Wang and Penner, 2009a). As shown in Fig. 6a, a clear correlation is found between the short-wave total aerosol forcing and the lower limit imposed on $N_{d}$ in the various models investigated here. This is also reflected in the finding that the $N_{d}-\tau_{a}$ relationship becomes weaker as larger minimum $N_{d}$ values are imposed (Fig. 6b). The presently missing explicit model treatment of microphysics in convective clouds may in effect lead to an increased $\mathrm{N}_{d}$ when convective water is detrained. In some parameterisations, droplets are assumed to activate at the base of convective clouds, but since collision/coalescence are not parameterised for the convective updrafts, $N_{d}$ is not appropriately reduced until it is detrained at higher altitudes (e.g. Lohmann et al., 2007). In other parameterisations, a constant droplet radius is assumed for the convective detrainment (e.g. Morrison and Gettelman, 2008), which is not directly related to aerosol activation and thus acts in effect similar to assuming a lower bound on $N_{d}$.

Figure 7 shows how the total all-sky modelled forcing over land and oceans may be described as a function of the 
Table 4. Global (land/sea) annual mean modelled and scaled short-wave aerosol forcings. Clear and cloudy sky forcings are scaled by the clear- and cloudy-sky fractions and add up to the total forcing. The inter-model median and standard deviations are given. The scaling is done using the relationships from Fig. 8c for clear sky, evaluated for anthropogenic $\tau_{a}$ from Bellouin et al. (2005) over ocean and from the model median over land; and using the relationship from Fig. $8 \mathrm{~d}$ for cloudy sky, evaluated for the $N_{d}-\tau_{a}$ relationship slope derived from MODIS Terra over both land and ocean. Since the model-median (rather than mean) is computed independently for clear, cloudy, and all-sky, clear plus cloudy forcings do not necessarily exactly add up to the all-sky value.

\begin{tabular}{|c|c|c|c|c|}
\hline & & Land & Ocean & Global \\
\hline \multirow[t]{3}{*}{ Model estimates } & Clear-sky short-wave aerosol forcing $\left[\mathrm{Wm}^{-2}\right]$ & $-0.40 \pm 0.36$ & $-0.24 \pm 0.19$ & $-0.27 \pm 0.23$ \\
\hline & Cloudy-sky short-wave aerosol forcing $\left[\mathrm{Wm}^{-2}\right]$ & $-1.27 \pm 0.77$ & $-0.93 \pm 0.44$ & $-1.13 \pm 0.51$ \\
\hline & All-sky short-wave aerosol forcing $\left[\mathrm{Wm}^{-2}\right]$ & $-1.83 \pm 0.89$ & $-1.40 \pm 0.51$ & $-1.53 \pm 0.60$ \\
\hline \multirow[t]{3}{*}{ Scaled model estimates } & Clear-sky short-wave aerosol forcing $\left[\mathrm{Wm}^{-2}\right]$ & $-0.53 \pm 0.25$ & $-0.30 \pm 0.18$ & $-0.38 \pm 0.19$ \\
\hline & Cloudy-sky short-wave aerosol forcing $\left[\mathrm{Wm}^{-2}\right]$ & $-0.39 \pm 0.12$ & $-0.82 \pm 0.52$ & $-0.70 \pm 0.37$ \\
\hline & All-sky short-wave aerosol forcing $\left[\mathrm{Wm}^{-2}\right]$ & $-0.98 \pm 0.32$ & $-1.12 \pm 0.57$ & $-1.15 \pm 0.43$ \\
\hline
\end{tabular}
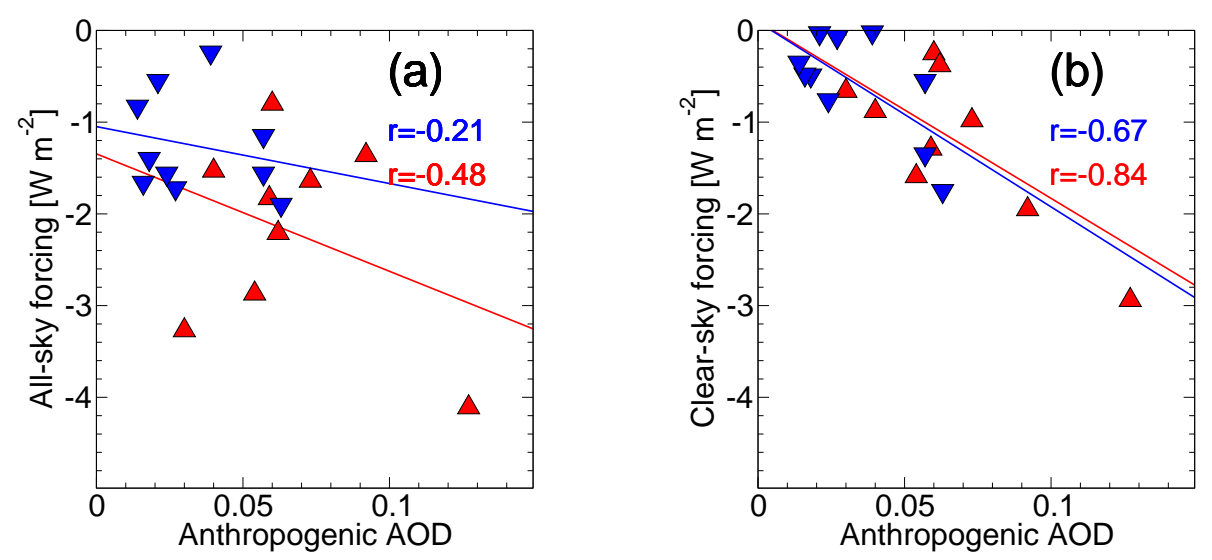

Fig. 5. Correlation between anthropogenic $\tau_{a}$ and (a) short-wave total aerosol forcing (b) short-wave clear-sky forcing over land (red) and oceans (blue) for the different models. The clear sky forcing is computed assuming a reference, cloud-free atmosphere. Global (land/ocean) annual mean values are given.

strength of the relationships of $\tau_{a}$ with $\alpha, N_{d}, f_{\text {cld }}$ and $L$. The correlation coefficients show that over oceans, the $\alpha-$ $\tau_{a}$ relationship strength is a good predictor for the forcing $\left(\mathrm{r}^{2}=0.46\right)$, but it is less good over land $\left(r^{2}=0.14\right)$. The slope of the $\alpha-\tau_{a}$ relationship as computed from the satellite retrievals may yield a forcing estimate if the dependency of the forcing on the $\alpha-\tau_{a}$ relationship strength is simulated reasonably well by the GCMs. This dependency is shown in Fig. 7 as a linear regression between the forcing and the $\alpha-\tau_{a}$ relationship slope. Using the $\alpha-\tau_{a}$ relationship slope obtained from the satellite data, an estimate of the total short-wave aerosol forcing may be derived. This yields $-2.6 \pm 1.1$ and $-1.5 \pm 0.6 \mathrm{Wm}^{-2}$ over land and ocean, respectively, where the error estimate is inferred from the statistical uncertainty of the regression in Figure $7 \mathrm{a}$ and the uncertainty of the satellite-derived slope inferred from the difference between the Terra and Aqua retrievals. Besides this uncertainty, an additional, unquantified positive bias is expected over land where the $\alpha-\tau_{a}$ relationship is overestimated for the satellite retrievals (see discussion above). The strengths of the relationships of $\tau_{a}$ with $N_{d}, f_{\text {cld }}$ and $L$ are less useful predictors for the forcing over ocean, with the strongest influence by the $N_{d}-\tau_{a}$ relationship. This is expected since it represents the most direct parameterisation of aerosol-cloud interactions in the GCMs. Over land, however, the $L-\tau_{a}$ relationship seems to be more important. The annual mean total aerosol shortwave forcing inferred from the relationship slopes computed from satellite data, combined with the dependency of the forcing on these slopes as shown in Fig. 7, would be $-1.8 \pm .0 .9,-3.1 \pm 1.3$ and $-1.7 \pm 0.4 \mathrm{Wm}^{-2}$ over land using the relationships between $\tau_{a}$ and $N_{d}, f_{\text {cld }}$ and $L$, respectively, and $-1.1 \pm 0.5,-1.2 \pm 0.4$ and $-1.1 \pm 0.2 \mathrm{Wm}^{-2}$ over ocean. These estimates using the three different scalings seem consistent with each other, yielding values of $-2.3 \pm 0.9 \mathrm{Wm}^{-2}$ over land and $-1.2 \pm 0.4 \mathrm{Wm}^{-2}$ over ocean. The corresponding global-mean value is $-1.5 \pm 0.5 \mathrm{Wm}^{-2}$. 

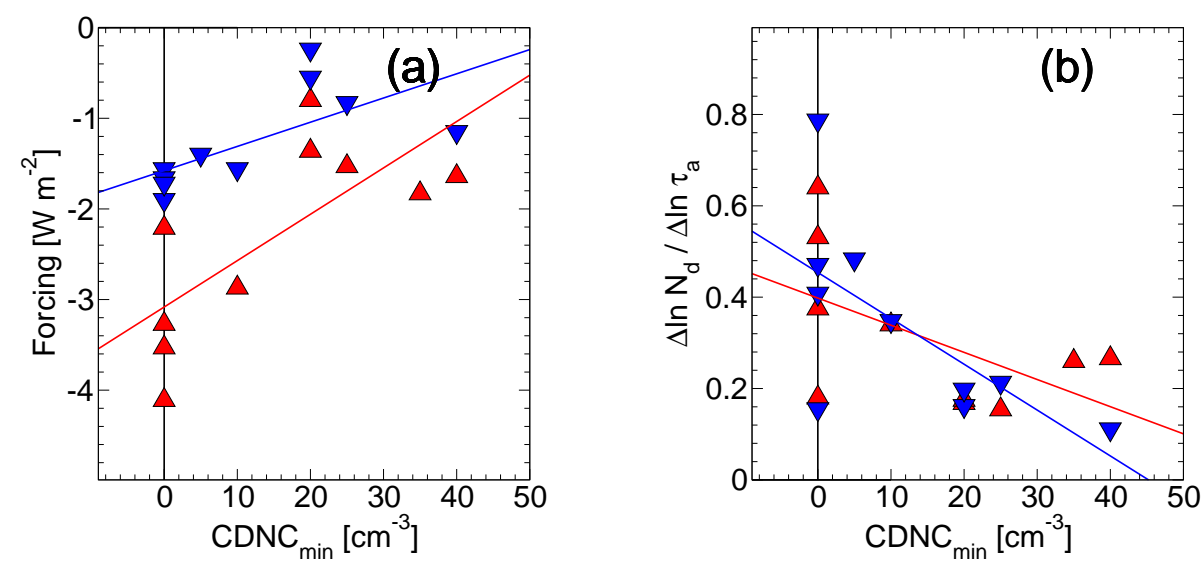

Fig. 6. The imposed lower limit on $N_{d}$ vs. (a) total short-wave aerosol radiative forcing and (b) relationship $N_{d}-\tau_{a}$ over land (red) and ocean (blue). ECHAM5 uses a lower limit of $40 \mathrm{~cm}^{-3}$; Hadley, $35 \mathrm{~cm}^{-3}$ over land and $5 \mathrm{~cm}^{-3}$ over ocean; SPRINTARS, $25 \mathrm{~cm}^{-3}$; GISS and LMDZ-INCA, $20 \mathrm{~cm}^{-2}$; CAM-Umich, $10 \mathrm{~cm}^{-3}$, and CAM-NCAR, CAM-Oslo, CAM-PNNL, and GFDL, no lower limit.
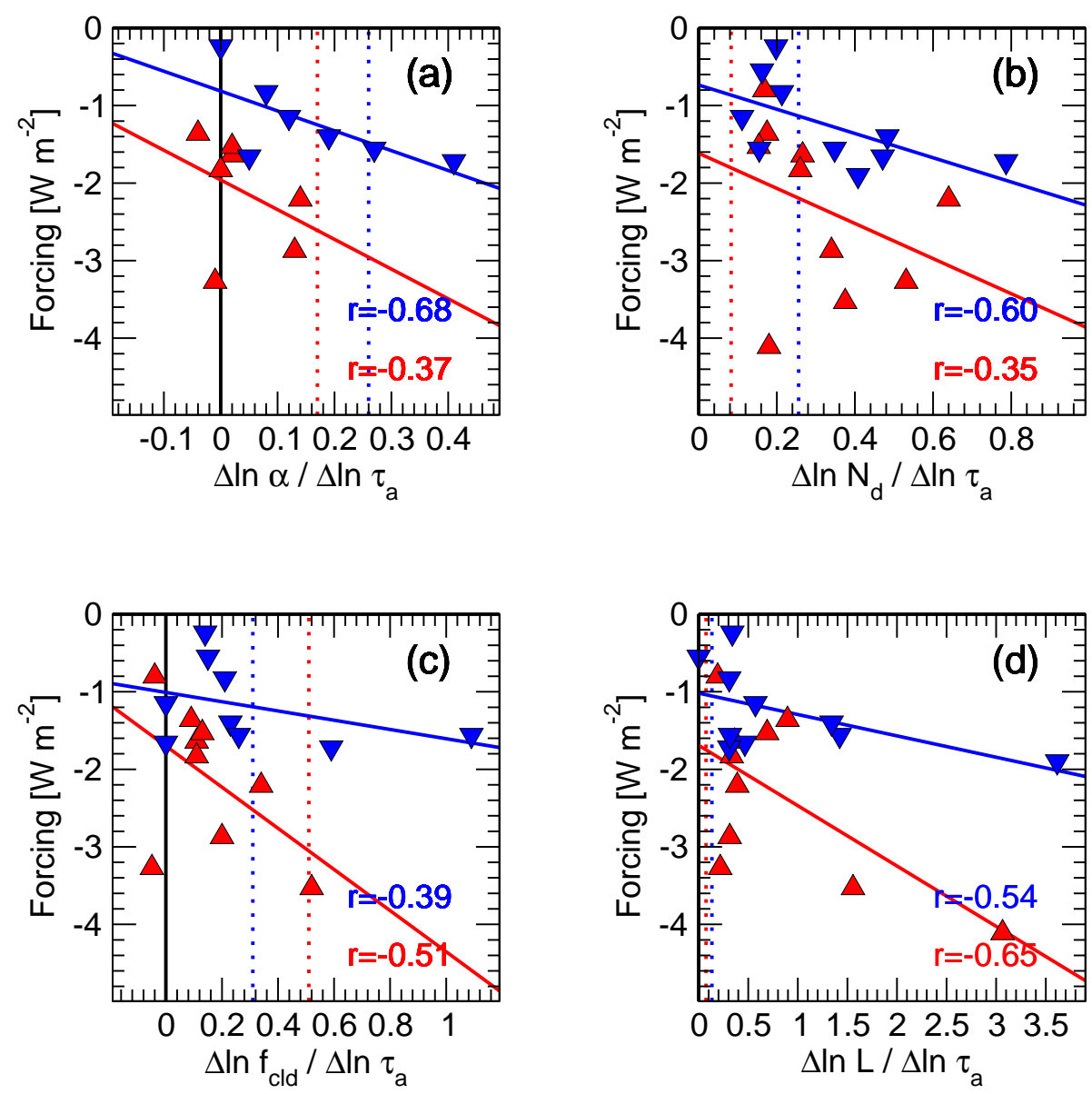

Fig. 7. Influence of the relationships between $\tau_{a}$ and (a) $\alpha$, (b) $N_{d}$, (c) $f_{\text {cld }}$ and (d) $L$ on the total short-wave aerosol forcing over land (red) and oceans (blue), for the up to ten different GCMs (the global mean data are listed in Table 3). The plain lines show the linear regression between the slopes and the forcing, and the dashed vertical lines show the slopes inferred from the MODIS Terra (MODIS-CERES-Terra for $\alpha$ ) satellite retrievals. 

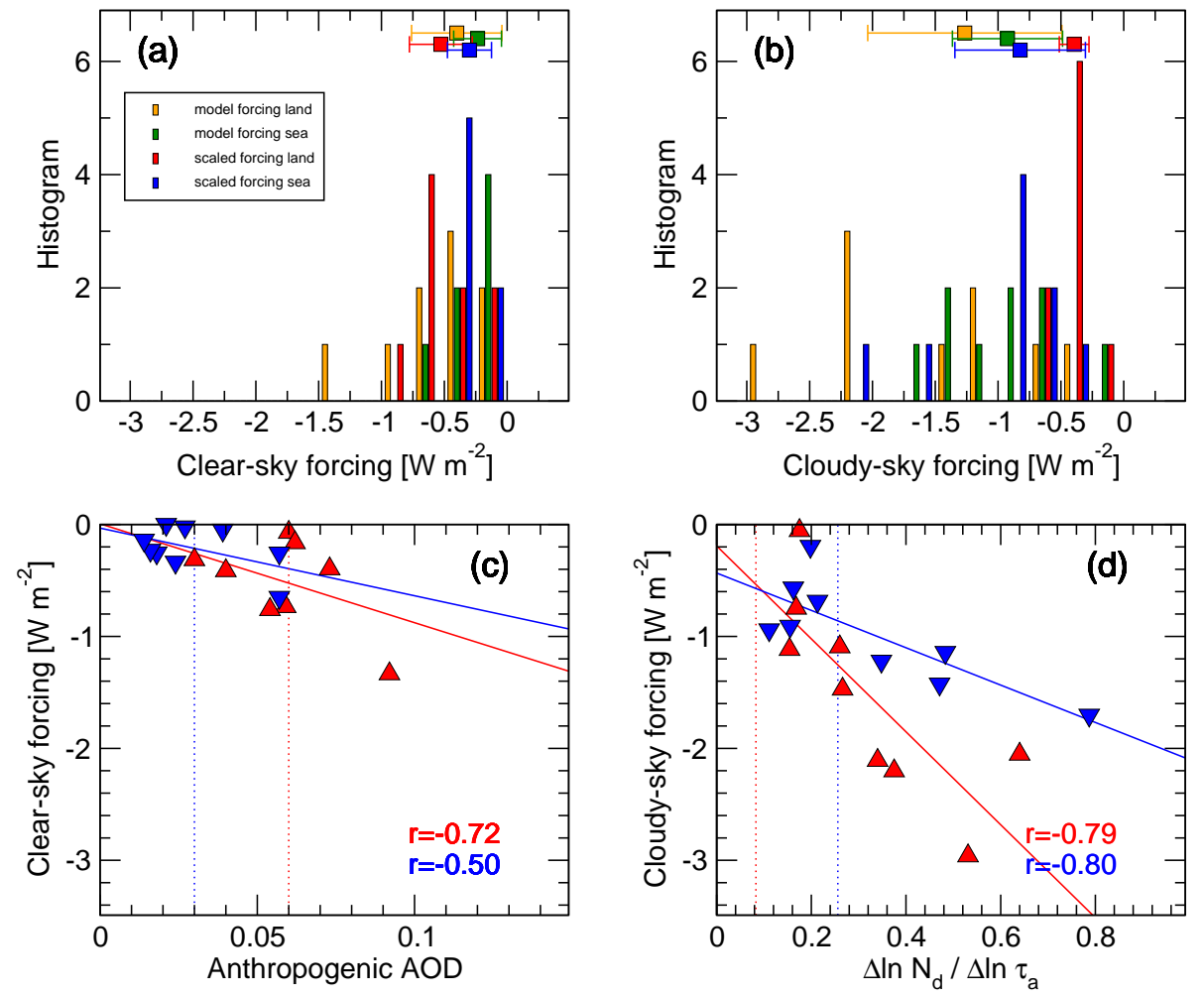

Fig. 8. Forcing estimates. (a) Clear-sky short-wave aerosol forcing histograms (in bins of width $0.25 \mathrm{Wm}^{-2}$ ) for the original model estimates as mean values over land (orange) and oceans (green); new estimates of the forcings over land (red) and ocean (blue), rescaled using the relationship clear sky forcing - anthropogenic $\tau_{a}$ shown in (c) applying the satellite-based estimate for anthropogenic $\tau_{a}$ by Bellouin et al. (2005) over oceans (dashed blue line) and the model-median anthropogenic $\tau_{a}$ over land (dashed red line). (b) Cloudy-sky short-wave aerosol forcing histograms $\left(0.25 \mathrm{Wm}^{-2}\right.$ bin width), with rescaled forcing estimate using the cloudy sky forcing vs. $N_{d}-\tau_{a}$-regression-slope relationship shown in (d) applying the MODIS Terra-derived $N_{d}-\tau_{a}$ slope estimates over land and ocean (shown as dashed vertical lines in (d) in red and blue, respectively). The median forcing values and standard deviation are shown on the top of (a) and (b) (see listing in Table 4). Clear and cloudy sky forcings are scaled by the clear and cloudy fraction as in Table 3.

Another, probably more reliable method to obtain a forcing estimate from a combination of the model results with the satellite-derived statistical relationships is to use the observations to scale each of the model forcings. For this purpose we separate clear-sky and cloudy-sky forcings. If the effects of absorbing aerosols in cloudy skies are neglected, this enables us to broadly separate aerosol direct (clear-sky) and indirect (cloudy-sky) radiative effects. Figure $8 \mathrm{c}$ repeats the result of Fig. 5 b, but for the clear-sky forcing weighted by the clearsky fraction as in Table 3. Figure 8a shows the distribution of the modelled clear-sky forcings. We scale these forcings with the ratio of anthropogenic $\tau_{a}$ from the individual models to the model-median one over land, and to the satellite-inferred anthropogenic $\tau_{a}$ over oceans (Bellouin et al., 2005). The reason for using the model-median over land is that a databased estimate of the anthropogenic $\tau_{a}$ over land is not available (Bellouin et al., 2005), and it has been shown that the median model is in many aspects superior to any individual model (Kinne et al., 2006; Schulz et al., 2006). The scaled clear-sky forcing distribution is narrower over both land and ocean, with median values strengthening to $-0.5 \pm 0.3 \mathrm{Wm}^{-2}$ and $-0.3 \pm 0.2 \mathrm{Wm}^{-2}$ over land and oceans, respectively (Table 4), with an uncertainty estimate from the inter-model standard deviation. The scaled global-mean model-median value for the clear-sky forcing (which corresponds to the aerosol direct effect if aerosol absorption in cloudy skies is neglected) is $-0.4 \pm 0.2 \mathrm{Wm}^{-2}$. Cloudy-sky forcings in the models are to a large extent determined by the $N_{d}-\tau_{a}$ relationship strength as shown in Fig. 8d $\left(r^{2}>0.6\right.$ over both land and ocean). Scaling the modelled cloudy-sky forcings by the $N_{d}-\tau_{a}$ relationship slope obtained from MODIS Terra, the forcing distribution becomes slightly broader over oceans, where the model-simulated $N_{d}-\tau_{a}$ relationships are relatively close to the satellite-retrieved ones, and much tighter over land (Fig. 8b). Since particularly over land, the dataderived $N_{d}-\tau_{a}$ relationship slope is smaller than the modelled ones, the median estimates weaken to $-0.4 \pm 0.1 \mathrm{Wm}^{-2}$ and $-0.8 \pm 0.5 \mathrm{Wm}^{-2}$ over land and ocean, respectively, with a scaled global-mean model-median value (corresponding to the aerosol indirect effects) of $-0.7 \pm 0.4 \mathrm{Wm}^{-2}$. The 
scaled all-sky short-wave median forcings are estimated as $-1.0 \pm 0.3 \mathrm{Wm}^{-2}$ and $-1.1 \pm 0.6 \mathrm{Wm}^{-2}$ over land and ocean, respectively, with a global annual mean value of $-1.2 \pm 0.4 \mathrm{Wm}^{-2}$ (Table 4 ; the medians are computed independently for land, ocean and global median values). Scaling with the Aqua rather than Terra $N_{d}-\tau_{a}$ slopes contributes to the error estimate only a negligible additional uncertainty ( \pm 0.02 over land and \pm 0.01 over ocean). The estimate over oceans agrees with the one presented above from the regressions found in Fig. 6, with the land estimate being much lower than (but still consistent with) the estimate from Fig. 6 . Note that the estimate over land from Fig. 6 might be highbiased (see above).

McComiskey and Feingold (2008) investigated how the radiative forcing by the first aerosol indirect effect (cloud albedo effect) varies for a given variation in the slope of the $N_{d}-\tau_{a}$ relationship. They find that the forcing varies by 3$10 \mathrm{Wm}^{-2}$ for an increase in the slope by 0.05 in scenes overcast with liquid water clouds with $L=50 \mathrm{~g} \mathrm{~m}^{-2}$. The lower limit of $3 \mathrm{Wm}^{-2}$ is found for an anthropogenic aerosol perturbation corresponding to an increase in $\mathrm{CCN}$ by a factor of 3 , and the upper limit of $10 \mathrm{Wm}^{-2}$, to an increase in $\mathrm{CCN}$ by a factor of 25 . This is roughly consistent with a logarithmic scaling of the forcing with the aerosol perturbation $\left(3 \mathrm{Wm}^{-2} / \ln 3 \approx 10 \mathrm{Wm}^{-2} / \mathrm{ln} 25 \approx 3 \mathrm{Wm}^{-2}\right)$. On a global average, the GCMs examined here show an increase in $\tau_{a}$ due to anthropogenic emissions of $30 \%$ (an increase by a factor of 1.3). Considering that about $25 \%$ of the globe is covered by liquid clouds according to satellite estimates, the estimate by McComiskey and Feingold (2008) would correspond to an uncertainty in global mean aerosol indirect forcing of $0.25 \times 3 \mathrm{Wm}^{-2} \times \ln 1.3 \approx 0.2 \mathrm{Wm}^{-2}$. When choosing their computations for $L=200 \mathrm{~g} \mathrm{~m}^{-2}$, the corresponding uncertainty is $0.1 \mathrm{Wm}^{-2}$. From Fig. $8 \mathrm{~d}$ we find that an uncertainty in the $N_{d}-\tau_{a}$ slope of 0.05 corresponds to a global-mean cloudy-sky forcing uncertainty of $0.1 \mathrm{Wm}^{-2}$ over oceans and $0.2 \mathrm{Wm}^{-2}$ over land, which is in rough agreement with the finding by McComiskey and Feingold according to the back-of-envelope calculation given here.

\section{Summary and conclusions}

Ten different GCMs were used to simulate aerosol-cloudradiation relationships diagnosed in a way consistent with passive satellite instruments. The relationships are compared to those derived from three different satellite instruments (MODIS on Terra and Aqua and ATSR-2 on ERS2; CERES on board of Terra and Aqua for the radiative fluxes). The satellite data are taken here as a reference, bearing in mind that the cloud and aerosol property retrievals include uncertainties. It is found that cloud droplet number concentration $\left(N_{d}\right)$ is positively correlated with aerosol optical depth $\left(\tau_{a}\right)$ in both satellite data and models, with models overestimating this relationship over land, sometimes inverting the distinct land-sea contrast found in the satellite data. Over oceans, most models simulate the strength of the relationship to well within a factor of two of the magnitude found in the observations. The $N_{d}-\tau_{a}$ relationship derived from satellites as well as from most models is also consistent with that obtained from ground-based remote sensing at a coastal site in California.

All models strongly overestimate the relationship between cloud liquid water path $(L)$ and $\tau_{a}$ compared to the satellite data, and the strength of this relationship is influenced by the autoconversion parameterisation. Thus, GCM cloud parameterisations need to be improved in order to properly represent second indirect effects.

The negative relationship between cloud top temperature and $\tau_{a}$ as obtained by the satellite retrievals is found in only one model in a consistent way. A reason for this may be that the relevant processes (in particular, microphysical influences on convective clouds and ice-phase processes) are not properly represented in the GCMs.

While the majority of the models simulate positive cloud fraction $\left(f_{\text {cld }}\right)-\tau_{a}$ relationships, these are in most cases weaker than the ones found in the satellite datasets. All but one model simulate a land-ocean contrast of opposite sign compared to the satellite relationships. In a discussion of the hypotheses proposed in the literature to explain the strong satellite-derived $f_{\text {cld }}-\tau_{a}$ relationship, our results indicate that none can be identified as a unique explanation.

The models that simulate the strongest $f_{\text {cld }}-\tau_{a}$ relationships are best able to capture the satellite-derived relationships between planetary albedo ( $\alpha)$ and $\tau_{a}$ (positive) and between OLR and $\tau_{a}$ (negative). These seem to be mainly determined by the cloud fraction sensitivity.

Particularly in clear skies, the short-wave radiative forcing (determined as the radiative flux perturbation) as modelled by the GCMs is to a large extent determined by the anthropogenic change in $\tau_{a}$, which varies by a factor of four among the models. Also the strengths of the relationships of $\tau_{a}$ with $\alpha, N_{d}, f_{\text {cld }}$ and $L$ as used here for the GCM evaluation, are good predictors for the short-wave total aerosol forcing. This finding in combination with the satellite-derived relationship strengths might be used to provide a short-wave total aerosol forcing estimate along with a statistical uncertainty estimate from a combination of models and satellite observations, which is about $-2.3 \pm 0.9 \mathrm{Wm}^{-2}$ and $-1.2 \pm 0.4 \mathrm{Wm}^{-2}$ over land and ocean, respectively, with a global mean value of $-1.5 \pm 0.5 \mathrm{Wm}^{-2}$. Alternatively, the modelled forcings can be scaled using the $N_{d}-\tau_{a}$ relationship slope as obtained from the satellite data for cloudy skies and an estimate of the anthropogenic fraction of $\tau_{a}$ for clear skies. This method yields a clear-sky global-mean forcing, corresponding to the aerosol direct effect if aerosol absorption in cloudy skies is neglected, of $-0.4 \pm 0.2 \mathrm{Wm}^{-2}$ estimated from the scaled model median and standard deviation. The cloudy-sky estimate, corresponding to the aerosol indirect effect, yields 
$-0.7 \pm 0.4 \mathrm{Wm}^{-2}$, and the all-sky forcing obtained by this method would be $-1.2 \pm 0.4 \mathrm{Wm}^{-2}$.

The evaluation studies presented here use just a few reference datasets, and focus on statistical relationships averaged over large scales. Future studies would need to include more observational datasets (including the active remote sensing from Cloudsat and Calipso), and investigate in more detail the spatial variability in aerosol-cloud interactions. It would be very valuable if future remote sensing retrievals would include quantitative error estimates, so that a realistic observations-based uncertainty beyond the diversity assessed here could be used.

\section{Appendix A}

\section{A1 CAM-NCAR}

The Community Atmosphere Model (CAM) is a modified version of NCAR CAM3 (Collins et al., 2006). The modifications include new two-moment microphysics (Gettelman et al., 2008; Morrison and Gettelman, 2008) including a physically based method for the aerosol activation of cloud droplets (Abdul-Razzak and Ghan, 2000), a diagnostic cloud cover scheme based on relative humidity after Slingo (1987) and a large-scale condensation scheme after Rasch and Kristjánsson (1998) updated by Zhang et al. (2003), and the MOZART Bulk Aerosol Model (BAM; Tie et al., 2005). The model includes sea salt, dust, sulfate and black and organic carbon.

\section{A2 CAM-Oslo}

The model is based on the NCAR CAM3 (Collins et al., 2006) with large-scale condensation described by Rasch and Kristjánsson (1998) and a diagnostic cloud cover scheme based on relative humidity after Slingo (1987). CAM-Oslo has been extended to include a two-moment warm cloud microphysics scheme (Storelvmo et al., 2006b; Hoose et al., 2009), coupled to a scheme for sea salt, dust, sulfate, black carbon, and organic aerosols and their optical and physical properties (Seland et al., 2008). The aerosol size distributions are described by 16 process modes and 44 bins with process-determined mixing states. Log-normal size-distributions are fitted for the calculation of cloud droplet activation based on Abdul-Razzak and Ghan (2000). Autoconversion is formulated following Rasch and Kristjánsson (1998). The simulations have been integrated for 5 years in T42L26 resolution.

\section{A3 CAM-PNNL}

The simulations were done using a development version of the Community Atmosphere Model (CAM) version cam 3.6.15 which includes a two-moment cloud microphysics scheme (Morrison and Gettelman, 2008), the RRTMG radiation package (Iacono et al., 2008), a diagnostic cloud cover scheme based on relative humidity after Slingo (1987) a large-scale condensation scheme after Rasch and Kristjánsson (1998) updated by Zhang et al. (2003), and a seven-mode version of modal aerosol treatment which predicts mass concentrations of aerosol species in Aitken, accumulation, primary carbon, fine and coarse dust and fine and coarse sea salt modes and aerosol number concentration in these modes (Liu et al., 2008). The simulation is run at $1.9^{\circ} \times 2.5^{\circ}$ resolution. The droplet activation is based on Abdul-Razzak and Ghan (2000) and only takes place at cloud base for preexisting clouds (i.e. when cloud fraction is constant in the grid). The autoconversion parameterisation is from Khairoutdinov and Kogan (2000).

\section{A4 CAM-Umich}

This is a coupled aerosol and atmospheric circulation model and consists of two components: the NCAR CAM3 atmospheric circulation model and the LLNL/Umich IMPACT aerosol model (Wang et al., 2009). The IMPACT aerosol model predicts aerosol mass for sea salt, dust, sulfate, black carbon and organic carbon (Liu et al., 2009). The original NCAR CAM3 model predicted both cloud liquid mass and cloud ice mass (Boville et al., 2006) and is updated with an additional prognostic equation for cloud liquid droplet number concentration (Wang and Penner, 2009b). The finite volume dynamical core was chosen for CAM. The coupled model is run for 5 years with 26 vertical levels and a $2^{\circ} \times 2.5^{\circ}$ horizontal resolution. The droplet activation is parameterised based on Köhler theory (Abdul-Razzak and Ghan, 2000, 2002) and the autoconversion parameterisation is described in Rasch and Kristjansson (1998). The treatment of large scale condensation and cloud fraction are described in detail in Zhang et al. (2003) and Bovile et al. (2006).

\section{A5 ECHAM5}

The atmospheric GCM (Roeckner et al., 2003) includes a detailed two-moment liquid and ice-cloud microphysical scheme (Lohmann et al., 2007) along with the modal aerosol scheme HAM considering sea salt, dust, sulfate, black carbon and organic carbon in seven internally mixed hydrophilic or hydrophobic log-normal modes including aerosol microphysical interactions (Stier et al., 2005). Large-scale condensation and cloud fraction are diagnosed using a relative humidity threshold (Sundqvist et al., 1989). The model is run at T42L19 resolution for the year 2000 nudged to ERA40 reanalyses. The droplet activation is parameterised following the empirical formulation by Lin and Leaitch (1997), and the autoconversion parameterisation is from Khairoutdinov and Kogan (2000). 


\section{A6 GFDL}

This study uses a prototypical version of the next-generation GFDL atmospheric GCM (Donner et al., 2009). It results from the continued development of its predecessor, AM2 (GAMDT, 2004), with the following main improvements. The finite-volume dynamical core (Lin, 2004) is implemented on cubed-sphere grids in the model. The model uses a combination of the shallow cumulus scheme of Bretherton et al. (2004) and the deep cumulus scheme of Donner (1993). A simplified tropospheric chemistry scheme (Ginoux et al., 2001) drives aerosol formation. The wet removal rate is scaled against large-scale and convective precipitation rates with different efficiencies. The interactions between aerosols and liquid water clouds are modeled using a prognostic scheme of cloud droplets (Ming et al., 2007) with a probability distribution of sub-grid updraft velocity related to turbulent diffusivity. All-sky radiative transfer calculations account for the effect of unresolved sub-grid-scale cloud distribution using the Monte Carlo Independent Column Approximation (Pincus et al., 2006). Note that like AM2, AM3 uses a prognostic scheme of large-scale cloud condensates and fraction (Tiedtke, 1993) with microphysics largely following Rotstayn (1997) and Rotstayn et al. (2000).

\section{A7 GISS}

The Goddard Institute for Space Studies climate model (Schmidt et al., 2006), ModelE $\left(4^{\circ} \times 5^{\circ}\right.$ horizontal resolution and 20 vertical layers) used in this study includes the indirect effects as described in Menon et al. (2008a, b). The prognostic equations for cloud droplet and ice crystal number concentrations follow the approach used in Morrison and Gettelman (2008) with the nucleation term as in Lohmann et al. (2007) and the autoconversion scheme from Rotstayn and Liu (2005). The cumulus and stratiform cloud parameterizations are as described in Del Genio and Yao (1993) and Del Genio et al. (1996, 2005). Stratiform cloud water is a prognostic variable and cloud formation is a function of available moisture convergence dependent on both relative humidity and stability conditions and is based on Sundqvist (1978) and Sundqvist et al. (1989).

The model is coupled to a aerosol chemistry and transport model (Koch et al., 2007; Bauer et al., 2007) and includes sulfates, nitrates, organic matter, black carbon, sea salt and dust as externally mixed species.

\section{A8 HadGEM}

The atmospheric component of the Hadley Centre Global Environmental Model version 2 (HadGEM2-A; Collins et al., 2008) includes schemes to simulate sulfate, black and organic carbon from fossil fuel, mineral dust and biomass burning aerosols as fully interactive prognostic fields, as well as a diagnostic scheme for sea salt aerosols and a fixed climatology of secondary organic aerosols from terpene emissions. All aerosol species exert a direct effect (and implicitly, a semi-direct effect) using prescribed size distributions, refractive index and hygroscopic growth curves. Those aerosols considered to be mainly hydrophilic (sulfate, sea salt, biomass burning, organic carbon, and secondary aerosol), which therefore act as $\mathrm{CCN}$, also contribute to both the first and second indirect effects on clouds, treating the aerosols as an external mixture as described in Jones et al. (2001). In HadGEM, the large-scale cloud scheme for liquid cloud diagnoses cloud water and cloud amount from total moisture and liquid water potential temperature using a triangular probability distribution function. The width of the distribution is diagnosed from the variability of the moisture and temperature of the surrounding grid points. Transfers between water categories (ice, liquid water, vapor, and rain) are calculated based on physical process equations using particle size information (Martin et al., 2006 and references therein). The model is run at N96L38 resolution for present-day and pre-industrial conditions, in free-running mode.

\section{A9 LMDZ-INCA}

The LMDZ model described in Hourdin et al. (2006) includes a cloud scheme based on a log-normal PDF representation of the cloud cover and the water content (Bony and Emanuel, 2001). The PDF depends on two parameters: the mean and variance of total water concentration. The distribution is assumed positively skewed. Precipitation formation depends only on the cloud water content, so no second aerosol indirect effects are included. The microphysical properties of water and ice clouds follow respectively Bony and Emmanuel (2001, Table 2 case "ICE_OPT" for water clouds and Table 3 for ice clouds). Temperature thresholds of $-15^{\circ} \mathrm{C}$ and $0^{\circ} \mathrm{C}$ are used for partionning cloud condensate into frozen and cloud water mixing ratios. The aerosol scheme is composed of seven log-normal modes that distinguish between soluble and insoluble aerosols. It represents dust, sea salt, sulfate, black carbon and organic carbon that can interact with the chemical species (Textor et al., 2006). The model resolution is $3.75^{\circ} \times 2.5^{\circ}$ with 19 vertical layers and it is nudged to the year 2000 of the ERA40 re-analysis. The indirect effect is parameterised using an empirical relationship between cloud droplet number concentration and aerosol mass based upon MODIS satellite retrievals (Quaas et al., 2006).

\section{A10 SPRINTARS}

The aerosol climate model, SPRINTARS, is driven by the GCM, MIROC (K-1 Model Developers, 2004), which is run at the horizontal and vertical resolutions of T106 and L20, respectively, in this study. It has a two-moment scheme both for liquid and ice clouds. The cloud droplet and ice crystal number concentrations are prognosed with number 
concentrations of black and organic carbons, sulfate, soil dust, and sea salt aerosols (Takemura et al., 2005, 2009). The parameterisation of cloud droplet activation and autoconversion are according to Abdul-Razzak and Ghan (2000) and Berry (1967), respectively. Cloud cover and condensate are diagnosed using an assumed top-hat total water distribution (Le Treut and Li, 1991).

Acknowledgements. CERES SSF data were obtained from the US National Aeronautics and Space Agency (NASA) Langley Research Center Atmospheric Sciences Data Center. The MODIS data used in this study were acquired as part of NASA's Earth Science Enterprise. The MODIS Science Teams developed the algorithms for the $\tau_{a}$ retrievals. The authors would like to thank the data distribution centers for their support. Computing time for the ECHAM5 model was provided by the German High Performance Computing Centre for Climate and Earth System Research (Deutsches Klimarechenzentrum, DKRZ). J. Q. was supported by an Emmy Noether grant of the German Research Foundation (DFG). The Met Office Hadley Centre is funded by the Joint DECC, Defra and MoD Integrated Climate Programme (DECC/Defra) GA01101, (MoD) CBC/2B/0417_Annex C5. The work with CAM-Oslo was supported by the projects EUCAARI (European Integrated project No. 036833-2), IPY POLARCAT and NorClim (Norwegian Research Council grant No. 178246), and supported by the Norwegian Research Council's program for Supercomputing through a grant of computer time. The work with LMDzT-INCA was supported by EUCAARI. The GFDL model was developed collectively by the GFDL Global Atmospheric Model Development Team (GAMDT). The Pacific Northwest National Laboratory is operated for the DOE by Battelle Memorial Institute under contract DE-AC06-76RLO 1830. The work at Lawrence Berkeley National Laboratory was supported by the US Department of Energy under Contract No. DE-AC02-05CH11231. S. M. acknowledges funding from the NASA MAP and DOE ARM program. The work of X. L., S. G. and R. E. was funded by US Department of Energy Atmospheric Radiation Measurement program and Scientific Discovery through Advanced Computing program. J. E. P. and M. W. were funded by NSF grant ATM 0609836 and NASA grant NNX08AL83G and acknowledge computer time provided by the NCAR CISL. The authors thank Leon Rotstayn, Ralph Kahn, Bjorn Stevens and Robert Wood for their helpful comments.

The service charges for this open access publication have been covered by the Max Planck Society.

Edited by: J. H. Seinfeld

\section{References}

Abdul-Razzak, H. and Ghan, S. J.: A parameterization of aerosol activation, 2. Multiple aerosol types, J. Geophys. Res., 105(D5), 6837-6844, 2000.

Abdul-Razzak, H. and Ghan, S. J.: A parameterization of aerosol activation, 3. Sectional representation, J. Geophys. Res., 107, 4026, doi:10.1029/2001JD000483, 2002.

Ackerman, A. S., Kirkpatrick, M. P., Stevens, D. E., and Toon, O. B.: The impact of humidity above stratiform clouds on indirect aerosol climate forcing, Nature, 432, 1014-1017, doi:10.1038/nature03174, 2004.

Albrecht, B. A.: Aerosols, cloud microphysics, and fractional cloudiness, Science, 245, 1227-1230, 1989.

Anderson, T. L., Charlson, R. J., Schwartz, S. E., Knutti, R., Boucher, O., Rodhe, H., and Heintzenberg, J.: Climate forcing by aerosols - A hazy picture, Science, 300, 1103-1104, 2003.

Andreae, M. O., Jones, C. D., and Cox, P. M.: Strong present-day aerosol cooling implies a hot future, Nature, 435, 1187-1190, 2005.

Andreae, M. O.: Correlation between cloud condensation nuclei concentration and aerosol optical thickness in remote and polluted regions, Atmos. Chem. Phys., 9, 543-556, 2009, http://www.atmos-chem-phys.net/9/543/2009/.

Bauer, S. E., Koch, D., Unger, N., Metzger, S. M., Shindell, D. T., and Streets, D. G.: Nitrate aerosols today and in 2030: a global simulation including aerosols and tropospheric ozone, Atmos. Chem. Phys., 7, 5043-5059, 2007,

http://www.atmos-chem-phys.net/7/5043/2007/.

Bellouin, N., Boucher, O., Haywood, J., and Reddy, M. S.: Global estimate of aerosol direct radiative forcing from satellite measurements, Nature, 438, 1138-1141, 2005.

Berry, E. X.: Cloud droplet growth by collection, J. Atmos. Sci., 24, 688-701, 1967.

Bony, S. and Emanuel, K. E.: A parameterization of the cloudiness associated with cumulus convection; evaluation using TOGA COARE data, J. Atmos. Sci., 58, 3158-3183, 2001.

Brenguier, J. L., Pawlowska, H., Schüller, L., Preusker, R., Fischer, J., and Fouquart, Y.: Radiative properties of boundary layer clouds: Droplet effective radius versus number concentration, J. Atmos. Sci., 57, 803-821, 2000.

Bréon, F.-M., Tanré, D., and Generoso, S.: Aerosol effect on cloud droplet size monitored from satellite, Science, 295, 834-838, 2002.

Bretherton, C. S., McCaa, J. R., and Grenier, H.: A new parameterization for shallow cumulus convection and its application to marine subtropical cloud-topped boundary layers, Part I: Description and 1-D Results, Mon. Weather Rev., 132, 864-882, 2004.

Charlson, R. J., Ackerman, A. S., Bender, F. A.-M., Anderson, T. L., and Liu, Z.: On the climate forcing consequences of the albedo continuum between cloudy and clear air, Tellus 59B, 715-727, 2007.

Collins, W. D., Rasch, P. J., Boville, B. A., Hack, J. J., McCaa, J. R., Williamson, D. L., Briegleb, B. P., Bitz, C. M., Lin, S. J., and Zhang, M.: The formulation and atmospheric simulation of the Community Atmosphere Model: CAM3, J. Climate, 19(11), 2122-2161, 2006.

Collins, W. J., Bellouin, N., Doutriaux-Boucher, M., Gedney, N., Hinton, T., Jones, C. D., Liddicoat, S., Martin, G., O'Connor, F., Rae, J., Senior, C., Totterdell, I., Woodward, S., Reichler, T., and Kim, J.: Evaluation of HadGEM2 model, Hadley Centre Technical Note 74, available at http://www.metoffice.gov.uk/ publications/HCTN/index.html last access: 11 November 2009, 2008.

Del Genio, A. D. and Yao, M.-S.: Efficient cumulus parameterization for long-term climate studies: The GISS scheme, The Representation of Cumulus Convection in Numerical Models, Meteor. Mon., 46, 181-184, 1993. 
Del Genio, A. D., Yao, M.-S., Kovari, W., and Lo, K. K.: A prognostic cloud water parameterization for general circulation models, J. Climate, 9, 270-304, 1996.

Del Genio, A. D., Kovari, W., Yao, M.-S., and Jonas, J.: Cumulus microphysics and climate sensitivity, J. Climate, 18, 2376-2387, 2005.

Denman, K. L., Brasseur, G., Chidthaisong, A., Ciais, P., Cox, P. M., Dickinson, R. E., Hauglustaine, D., Heinze, C., Holland, E., Jacob, D., Lohmann, U., Ramachandran, S., da Silva Dias, P. L., Wofsy, S. C., and Zhang, X.: Couplings Between Changes in the Climate System and Biogeochemistry, in: Climate Change 2007: The Physical Science Basis, Contribution of Working Group I to the Fourth Assessment Report of the Intergovernmental Panel on Climate Change, edited by: Solomon, S., Qin, D., Manning, M., Chen, Z., Marquis, M., Averyt, K. B., Tignor, M., and Miller, H. L., Cambridge University Press, Cambridge, UK and New York, NY, USA, 2007.

Dentener, F., Kinne, S., Bond, T., Boucher, O., Cofala, J., Generoso, S., Ginoux, P., Gong, S., Hoelzemann, J. J., Ito, A., Marelli, L., Penner, J. E., Putaud, J.-P., Textor, C., Schulz, M., van der Werf, G. R., and Wilson, J.: Emissions of primary aerosol and precursor gases in the years 2000 and 1750 prescribed data-sets for AeroCom, Atmos. Chem. Phys., 6, 4321-4344, 2006,

http://www.atmos-chem-phys.net/6/4321/2006/.

Devasthale, A., Krüger, O., and Grassl, H.: Change in cloud-top temperatures over Europe, IEEE Geosci. Remote S., 2, 333-336, doi:10.1109/LGRS.2005.851736, 2005.

Donner, L. J.: A cumulus parameterization including mass fluxes, vertical momentum dynamics, and Mesoscale Effects, J. Atmos. Sci., 50, 889-906, 1993.

Donner, L. J., Wyman, B. L., Hemler, R. S., Horowitz, L. W., Ming, Y., Zhao, M., Golaz, J.-C., Austin, J., Cooke, W. F., Freidenreich, S. R., Ginoux, P., Gordon, C. T., Griffies, S., Held, I. M., Hurlin, W. J., Klein, S. A., Langenhorst, A. R., Lee, H.-C., Lin, S.-J., Maleyshev, S. L., Milly, P. C. D., Nath, M. J., Pincus, R., Ploshay, J. J., Ramaswamy, V., Schwarzkopf, M. D., Seman, C. J., Shevliakova, E., Sirutis, J. J., Stern, W. F., Stouffer, R. J., Wilson, R. J., Winton, M., and Wittenberg, A. T.: The dynamical core, physical parameterizations, and basic simulation characteristics of the atmospheric component of the GFDL global Coupled Model CM3, J. Climate, in preparation, 2009.

Gettelman, A., Morrison, H., and Ghan, S. J.: A new two-moment bulk stratiform cloud microphysics scheme in the NCAR Community Atmosphere Model (CAM3), part II: Single-column and global results, J. Climate, 21(15), 3660-3679, 2008.

Ghan, S. J., Easter, R., Chapman, E., Abdul-Razzak, H., Zhang, Y., Leung, L., Laulainen, N., Saylor, R., and Zaveri, R.: A physically based estimate of radiative forcing by anthropogenic sulfate aerosol, J. Geophys. Res., 106, 5279-5293, 2001.

Ginoux, P., Chin, M., Tegen, I., Prospero, J., Holben, B., Dubovik, O., and Lin, S.-J.: Sources and distributions of dust aerosols simulated with the GOCART model, J. Geophys. Res., 106(D17), 20255-20273, 2001.

Guo, H., Penner, J. E., Herzog, M., and Pawlowska, H.: Examination of the aerosol indirect effect under contrasting environments during the ACE-2 experiment, Atmos. Chem. Phys., 7, 535-548, 2007 ,

http://www.atmos-chem-phys.net/7/535/2007/.

Feingold, G.: Modeling of the first indirect effect: Analysis of measurement requirements, Geophys. Res. Lett., 30(19), 1997, doi:10.1029/2003GL017967, 2003.

Feingold, G., Eberhard, W. L., Veron, D. E., and Previdi, M.: First measurements of the Twomey indirect effect using ground-based remote sensors, Geophys. Res. Lett., 30(6), 1287, doi:10.1029/2002GL016633, 2003.

Haywood, J. M., Ramaswamy, V., and Donner, L. J.: A limitedarea-model case study of the effects of sub-grid scale variations in relative humidity and cloud upon the direct radiative forcing of sulfate aerosol, Geophys. Res. Lett., 24(2), 143-146, 1997.

Hoose, C., Kristjánsson, J. E., Iversen, T., Kirkevåg, A., Seland, Ø., and Gettelman, A.: Constraining cloud droplet number concentration in GCMs suppresses the aerosol indirect effect, Geophys. Res. Lett., 36, L12807, doi:10.1029/2009GL038568, 2009.

Hourdin, F., Musat, I., Bony, S., Braconnot, P., Codron, F., Dufresne, J. L., Fairhead, L., Filiberti, M. A., Friedlingstein, P., Grandpeix, J. Y., Krinner, G., Levan, P., Li, Z. X., and Lott, F.: The LMDZ4 general circulation model: Climate performance and sensitivity to parametrized physics with emphasis on tropical convection, Clim. Dynam., 27, 787-813, 2006.

Iacono, M. J., Delamere, J. S., Mlawer, E. J., Shephard, M. W., Clough, S. A., and Collins, W. D.: Radiative forcing by long-lived greenhouse gases: Calculations with the AER radiative transfer models, J. Geophys. Res., 113, D13103, doi:10.1029/2008JD009944, 2008.

IPCC: Climate change 2007 - The scientific basis, Contribution of working group I to the Fourth Assessment Report of the Intergovernmental Panel on Climate Change, Cambridge University Press, Cambridge, 2007.

Jones, A., Roberts, D. L., Woodage, M. J., and Johnson, C. E.: Indirect sulphate aerosol forcing in a climate model with an interactive sulphur cycle, J. Geophys. Res., 106(D17), 20293-20310, 2001.

Jones, A., Haywood, J. M., and Boucher, O.: Aerosol forcing, climate response and climate sensitivity in the Hadley Centre climate model, J. Geophys. Res., 112, D20211, doi:10.1029/2007JD008688, 2007.

K-1 Model Developers: K-1 coupled GCM (MIROC) description, edited by: Hasumi, H. and Emori, S., Center for Climate System Research, University of Tokyo, Tokyo, Japan, K-1 Tech. Rep. 1, 34 pp., 2004.

Kaufman, Y. J., Koren, I., Remer, L., Rosenfeld, D., and Rudich, I.: The effect of smoke, dust, and pollution aerosol on shallow cloud development over the Atlantic Ocean, P. Natl. Acad. Sci., 102, 11207-11212, 2005.

Kaufman, Y. J. and Koren, I.: Smoke and pollution aerosol effect on cloud cover, Science, 313, 655-658, doi:10.1126/science.1126232, 2006.

Khairoutdinov, M. and Kogan, Y.: A new cloud physics parameterization in a large-eddy simulation model of marine stratocumulus, Mon. Weather Rev., 128, 229-243, 2000.

Kinne, S., Schulz, M., Textor, C., Guibert, S., Balkanski, Y., Bauer, S. E., Berntsen, T., Berglen, T. F., Boucher, O., Chin, M., Collins, W., Dentener, F., Diehl, T., Easter, R., Feichter, J., Fillmore, D., Ghan, S., Ginoux, P., Gong, S., Grini, A., Hendricks, J., Herzog, M., Horowitz, L., Isaksen, I., Iversen, T., Kirkevåg, A., Kloster, S., Koch, D., Kristjansson, J. E., Krol, M., Lauer, A., Lamarque, J. F., Lesins, G., Liu, X., Lohmann, U., Montanaro, V., Myhre, G., Penner, J., Pitari, G., Reddy, S., Seland, O., Stier, 
P., Takemura, T., and Tie, X.: An AeroCom initial assessment optical properties in aerosol component modules of global models, Atmos. Chem. Phys., 6, 1815-1834, 2006, http://www.atmos-chem-phys.net/6/1815/2006/.

Koch, D., Bond, T. C., Streets, D., and Unger, N.: Linking future aerosol readiative forcing to shifts in source activities, Geophys. Res. Lett., 34, L05821, doi:10.1029/2006GL028360, 2007.

Koch, D., Menon, S., Del Genio, A., Ruedy, R., Alienov, I., and Schmidt, G. A.: Distinguishing aerosol impacts on climate over the past century, J. Climate, 22, 2659-2677, 2009.

Koren, I., Kaufman, Y. J., Rosenfeld, D., Remer, L. A., and Rudich, Y.: Aerosol invigoration and restructuring of Atlantic convective clouds, Geophys. Res. Lett., 32, L14828, doi:10.1029/2005GL023187, 2005.

Koren, I., Remer, L. A., Kaufman, Y. J., Rudich, Y., and Martins, J. V.: On the twilight zone between clouds and aerosols, Geophys. Res. Lett., 34, L08805, doi:10.1029/2007GL029253, 2007.

Krüger, O. and Graß1, H.: The indirect aerosol effect over Europe, Geophys. Res. Lett. 29, 1925-1929, 2002.

Lee, S. S., Penner, J. E., and Saleeby, S. M.: Aerosol effects on liquid-water path of thin stratocumulus clouds, J. Geophys. Res., 114, D07204, doi:10.1029/2008JD010513, 2009a.

Lee, S. S. and Penner, J. E.: Comparison of a global-climate model to a cloud-system resolving model for the long-term response of thin stratocumulus clouds to preindustrial and present-day aerosol conditions, Atmos. Chem. Phys. Discuss., 9, 2131721369, 2009,

http://www.atmos-chem-phys-discuss.net/9/21317/2009/.

Le Treut, H. and Li, Z.-X.: Sensitivity of an atmospheric general circulation model to prescribed SST changes: Feedback processes associated with the simulation of cloud properties, Clim. Dynam., 5, 175-187, 1991.

Lin, H. and Leaitch, W. R.: Development of an in-cloud aerosol activation parameterization for climate modelling, Proceedings of the WMO Workshop on Measurement of Cloud Properties for Forecasts of Weather, Air Quality and Climate, Mexico City, June, 328-335, 1997.

Lin, S. J.: A "Vertically Lagrangian" finite-volume dynamical core for global models, Mon. Weather Rev., 132, 2293-2307, 2004.

Liu, X., Ghan, S., Easter, R., Zaveri, R., Gettelman, A., Rasch, P., Morrison, H., Hess, P., Lamarque, J. F., Mahowald, N., Vitt, F. M., Cameron-Smith, P., Chuang, C. C., and Ekman, A.: Indirect effect in NCAR CAM: Sensitivity to aerosol-cloud parameterizations. Presented at the American Geophysical Union Annual Meeting, 15-19 December 2008, San Francisco, California, 2008.

Liu, X., Penner, J. E., and Wang, M.: Influence of anthropogenic sulfate and black carbon on upper tropospheric clouds in the NCAR CAM3 model coupled to the IMPACT global aerosol model, J. Geophys. Res., 114, D03204, doi:10.1029/2008JD010492, 2009.

Loeb, N. G. and Manalo-Smith, N.: Top-of-atmosphere direct radiative effect of aerosols over global oceans from merged CERES and MODIS observations, J. Climate, 18, 3506, 2005.

Loeb, N. G. and Schuster, G. L.: An observational study of the relationship between cloud, aerosol and meteorology in broken low-level cloud conditions, J. Geophys. Res., 113, D14214, doi:10.1029/2007JD009763, 2008.

Lohmann, U. and Feichter, J.: Impact of sulfate aerosols on albedo and lifetime of clouds: A sensitivity study with the ECHAM4 GCM, J. Geophys. Res., 102(D12), 13685-13700, 1997.

Lohmann, U. and Feichter, J.: Global indirect aerosol effects: a review, Atmos. Chem. Phys., 5, 715-737, 2005, http://www.atmos-chem-phys.net/5/715/2005/.

Lohmann, U., Stier, P., Hoose, C., Ferrachat, S., Kloster, S., Roeckner, E., and Zhang, J.: Cloud microphysics and aerosol indirect effects in the global climate model ECHAM5-HAM, Atmos. Chem. Phys., 7, 3425-3446, 2007,

http://www.atmos-chem-phys.net/7/3425/2007/.

Martin, G. M., Ringer, M. A., Pope, V. D., Jones, A., Dearden, C., and Hinton, T. J.: The physical properties of the atmosphere in the new Hadley Centre Global Environment Model (HadGEM1), Part I: Model description and global climatology, J. Climate, 19, 1274-1301, 2006.

Mauger, G. S. and Norris, J. R.: Meteorological bias in satellite estimates of aerosol-cloud relationships, Geophys. Res. Lett., 34, L16824, doi:10.1029/2007GL029952, 2007.

McComiskey, A. and Feingold, G.: Quantifying error in the radiative forcing of the first aerosol indirect effect, Geophys. Res. Lett., 35, L02810, doi:10.1029/2007GL032667, 2008.

McComiskey, A., Feingold, G., Frisch, A. S., Turner, D., Miller, M., Chiu, J., Min, Q., and Ogren, J.: An assessment of aerosol-cloud interactions in marine stratus clouds based on surface remote sensing, J. Geophys. Res., 114, D09203, doi:10.1029/2008JD011006, 2009.

Menon, S., Brenguier, J.-L., Boucher, O., Davison, P., Del Genio, A. D., Feichter, J., Ghan, S., Guibert, S., Liu, X., Lohmann, U., Pawlowska, H., Penner, J. E., Quaas, J., Roberts, D. L., Schüller, L., and Snider, J.: Evaluating aerosol/cloud/radiation process parameterizations with single column models and ACE2 cloudy column observations, J. Geophys. Res., 108, 4762, doi:10.1029/2003JD003902, 2003.

Menon, S., Del Genio, A. D., Kaufman, Y. J., Bennartz, R., Koch, D., Loeb, N., and Orlikowski, D.: Analyzing signatures of aerosol-cloud interactions from satellite retrievals and the GISS GCM to constrain the aerosol indirect effect, J. Geophys. Res., 113, D14S22, doi:10.1029/2007JD009442, 2008a.

Menon, S., Unger, N., Koch, D., Francis, J., Garrett, T., Sednev, I., Shindell, D., and Streets, D.: Aerosol climate effects and air quality impacts from 1980 to 2030, Environ. Res. Lett., 3, 12 pp., doi:10.1088/1748-9326/3/2/024004, 2008b.

Ming, Y., Ramaswamy, V., Donner, L. J., Phillips, V. T. J., Klein, S. A., Ginoux, P. A., and Horowitz, L. W.: Modeling the interactions between aerosols and liquid water clouds with a selfconsistent cloud scheme in a general circulation model, J. Atmos. Sci., 64, 1189-1209, 2007.

Minnis, P., Sun-Mack, D. F., Heck, P. W., Doelling, D. R., and Trepte, Q. Z.: CERES cloud property retrievals from imagers on TRMM, Terra, and Aqua. Proc. SPIE 10th International Symposium on Remote Sensing: Conference on Remote Sensing of Clouds and the Atmosphere VII, Barcelona, Spain, 8-12 September, 37-48, 5235 pp., 2003.

Morrison, H. and Gettelman, A.: A new two-moment bulk stratiform cloud microphysics scheme in the Community Atmosphere Model, version 3 (CAM3), Part I: Description and numerial tests, J. Climate, 21, 3642-3659, 2008.

Myhre, G., Stordal, F., Johnsrud, M., Kaufman, Y. J., Rosenfeld, 
D., Storelvmo, T., Kristjansson, J. E., Berntsen, T. K., Myhre, A., and Isaksen, I. S. A.: Aerosol-cloud interaction inferred from MODIS satellite data and global aerosol models, Atmos. Chem. Phys., 7, 3081-3101, 2007,

http://www.atmos-chem-phys.net/7/3081/2007/.

Nakajima, T., Higurashi, A., Kawamoto, K., and Penner, J. E.: A possible correlation between satellite-derived cloud and aerosol microphysical parameters, Geophys. Res. Lett., 28, 1171-1174, 2001.

Penner, J. E., Quaas, J., Storelvmo, T., Takemura, T., Boucher, O., Guo, H., Kirkevåg, A., Kristjánsson, J. E., and Seland, Ø.: Model intercomparison of indirect aerosol effects, Atmos. Chem. Phys., 6, 3391-3405, 2006, http://www.atmos-chem-phys.net/6/3391/2006/.

Pincus, R., and Baker, M. B.: Effect of precipitation on the albedo susceptibility of clouds in the marine boundary layer, Nature, 372, 250-252, 1994.

Pincus, R., Hemler, R., and Klein, S. A.: Using stochastically generated subcolumns to represent cloud structure in a large-scale model, Mon. Weather Rev., 134, 3644-3656, 2006.

Poulsen, C. A., Campmany, E., Dean, S., Ewen, G., Sayer, A. M., Thomas, G. E., Grainger, R. G., Siddans, R., Lawrence, B., and Watts, P.: The ORAC ATSR-2 cloud retrieval algorithm for GRAPE, in preparation for the RSE AATSR special issue, 2009.

Platnick, S., King, M. D., Ackerman, S. A., Menzel, W. P., Baum, B. A., Riédi, J. C., and Frey, R. A.: The MODIS cloud products: Algorithms and examples from Terra, IEEE T. Geosci. Remote S., 41, 459-473, 2003.

Quaas, J., Boucher,O., and Bréon, F.-M.: Aerosol indirect effects in POLDER satellite data and in the LMDZ GCM, J. Geophys. Res., 109, D08205, doi:10.1029/2003JD004317, 2004.

Quaas, J., Boucher, O., and Lohmann, U.: Constraining the total aerosol indirect effect in the LMDZ and ECHAM4 GCMs using MODIS satellite data, Atmos. Chem. Phys., 6, 947-955, 2006, http://www.atmos-chem-phys.net/6/947/2006/.

Quaas, J., Boucher, O., Bellouin, N., and Kinne, S.: Satellite-based estimate of the direct and indirect aerosol climate forcing, J. Geophys. Res., 113, D05204, doi:10.1029/2007JD008962, 2008.

Quaas, J., Bony, S., Collins, W. D., Donner, L., Illingworth, A. J., Jones, A., Lohmann, U., Satoh, M., Schwartz, S. E., Tao, W.K., and Wood, R.: Current understanding and quantification of clouds in the changing climate system and strategies for reducing critical uncertainties, edited by: Heintzenberg, J. and Charlson, R. J., Perturbed Clouds in the Climate System, Proceedings Ernst Strüngmann Forum, MIT press, Cambridge, ISBN 978-0-26201287-4, p. 576, 2009.

Rasch, P. J. and Kristjánsson, J. E.: A comparison of the CCM3 model climate using diagnosed and predicted condensate parameterizations, J. Climate, 11, 1587-1614, 1998.

Remer, L. A., Kaufman, Y. J., Tanré, D., Mattoo, S., Chu, D. A., Martins, J. V., Li, R. R., Ichoku, C., Levy, R. C., Kleidman, R. G., Eck, T. F., Vermote, E., and Holben, B. N.: The MODIS algorithm, products, and validation, J. Atmos. Sci., 62, 947-973, doi:10.1175/JAS3385.1, 2005.

Roeckner, E., Bäuml, G., Bonaventura, L., Brokopf, R., Esch, M., Giorgetta, M., Hagemann, S., Kirchner, I., Kornblueh, L., Manzini, E., Rhodin, A., Schlese, U., Schulzweida, U., and Tompkins, A.: The atmospheric general circulation model ECHAM5: Part I: Model description, Report No. 349, Max
Planck Institute for Meteorology, Hamburg, 127 pp., 2003.

Rotstayn, L. D.: A physically based scheme for the treatment of stratiform clouds and precipitation in large-scale models. 1: Description and evaluation of microphysical processes, Q. J. Roy. Meteorol. Soc., 123, 1227-1282, 1997.

Rotstayn, L. D., Ryan, B., and Katzfey, J.: A scheme for calculation of the liquid fraction in mixed-phase clouds in large-scale models, Mon. Weather Rev., 128, 1070-1088, 2000.

Rotstayn, L. D. and Penner, J. E.: Forcing, quasi-forcing and climate response, J. Climate, 14, 2960-2975, 2001.

Rotstayn, L. D. and Liu, Y.: A smaller global estimate of the second indirect aerosol effect, Geophys. Res. Lett., 32, L05708, doi:10.1029/2004GL021922, 2005.

Schmidt, G. A., Ruedy, R., Hansen, J. E., Aleinov, I., Bell, N., Bauer, M., Bauer, S., Cairns, B., Canuto, V., Cheng, Y., Del Genio, A., Faluvegi, G., Friend, A. D., Hall, T. M., Hu, Y., Kelley, M., Kiang, N. Y., Koch, D., Lacis, A. A., Lerner, J., Lo, K. K., Miller, R. L., Nazarenko, L., Oinas, V., Perlwitz, J., Perlwitz, J., Rind, D., Romanou, A., Russell, G. L., Sato, M., Shindell, D. T., Stone, P. H., Sun, S., Tausnev, N., Thresher, D., and Yao, M.-S.: Present day atmospheric simulations using GISS ModelE: Comparison to in-situ, satellite and reanalysis data, J. Climate, 19, 153-192, 2006.

Schulz, M., Textor, C., Kinne, S., Balkanski, Y., Bauer, S., Berntsen, T., Berglen, T., Boucher, O., Dentener, F., Guibert, S., Isaksen, I. S. A., Iversen, T., Koch, D., Kirkevåg, A., Liu, X., Montanaro, V., Myhre, G., Penner, J. E., Pitari, G., Reddy, S., Seland, Ø., Stier, P., and Takemura, T.: Radiative forcing by aerosols as derived from the AeroCom present-day and pre-industrial simulations, Atmos. Chem. Phys., 6, 5225-5246, 2006,

http://www.atmos-chem-phys.net/6/5225/2006/.

Sekiguchi, M., Nakajima, T., Suzuki, K., Kawamoto, K., Higurashi, A., Rosenfeld, D., Sano, I., and Mukai, S.: A study of the direct and indirect effects of aerosols using global satellite data sets of aerosol and cloud parameters, J. Geophys. Res., 108(D22), 4699, doi:10.1029/2002JD003359, 2003.

Seland, Ø., Iversen, T., Kirkevåg, A., and Storelvmo, T.: Aerosolclimate interactions in the CAM-Oslo atmospheric GCM and investigation of associated basic shortcomings, Tellus, 60A, 459491, 2008.

Shine, K. P., Cook, J., Highwood, E. J., and Joshi, M. M.: An alternative to radiative forcing for estimating the relative importance of climate change mechanisms, Geophys. Res. Lett., 30, 2047, doi:10.1029/2003GL018141, 2003.

Slingo, J. M.: The development and verification of a cloud prediction scheme for the ECMWF model, Q. J. Roy. Meteorol. Soc., 113, 899-927, 1987.

Stevens, B. and Brenguier, J.-L.: Cloud controlling factors low clouds, edited by: Heintzenberg, J. and Charlson, R. J., Perturbed Clouds in the Climate System, Proceedings Ernst Strüngmann Forum, MIT press, Cambridge, ISBN 978-0-26201287-4, p. 576, 2009.

Stier, P., Feichter, J., Kinne, S., Kloster, S., Vignati, E., Wilson, J., Ganzeveld, L., Tegen, I., Werner, M., Balkanski, Y., Schulz, M., Boucher, O., Minikin, A., and Petzold, A.: The aerosolclimate model ECHAM5-HAM, Atmos. Chem. Phys., 5, 11251156, 2005, http://www.atmos-chem-phys.net/5/1125/2005/. 
Storelvmo, T., Kristjánsson, J. E., Myhre, G., Johnsrud, M., and Stordal, F.: Combined observational and modeling based study of the aerosol indirect effect, Atmos. Chem. Phys., 6, 3583-3601, 2006 , http://www.atmos-chem-phys.net/6/3583/2006/.

Storelvmo, T., Kristjánsson, J. E., Ghan, S. J., Kirkevåg, A., Seland, $\varnothing$., and Iversen,:. Predicting cloud droplet number concentration in Community Atmosphere Model (CAM)-Oslo, J. Geophys. Res., 111, D24208, doi:10.1029/2005JD006300, 2006 b.

Sundqvist, H.: A parameterization scheme for nonconvective condensation including prediction of cloud water content, Q. J. Roy. Meteorol. Soc., 104, 677-690, 1978.

Sundqvist, H., Berge, E., and Kristiansson, J. E.: Condensation and Cloud Parameterization Studies with a Mesoscale Numerical Weather Prediction Model, Mon. Weather Rev., 117, 1641-1657, 1989.

Suzuki, K. and Stephens, G. L.: Global identification of warm cloud microphysical processes with combined use of A-Train observations, Geophys. Res. Lett., 35, L08805, doi:10.1029/2008GL033590, 2008.

Takemura, T., Nozawa, T., Emori, S., Nakajima, T. Y., and Nakajima, T.: Simulation of climate response to aerosol direct and indirect effects with aerosol transport-radiation model, J. Geophys. Res., 110, D02202, doi:10.1029/2004JD005029, 2005.

Takemura, T., Egashira, M., Matsuzawa, K., Ichijo, H., O'ishi, R., and Abe-Ouchi, A.: A simulation of the global distribution and radiative forcing of soil dust aerosols at the Last Glacial Maximum, Atmos. Chem. Phys., 9, 3061-3073, 2009,

http://www.atmos-chem-phys.net/9/3061/2009/.

Textor, C., Schulz, M., Guibert, S., Kinne, S., Balkanski, Y., Bauer, S., Berntsen, T., Berglen, T., Boucher, O., Chin, M., Dentener, F., Diehl, T., Easter, R., Feichter, H., Fillmore, D., Ghan, S., Ginoux, P., Gong, S., Grini, A., Hendricks, J., Horowitz, L., Huang, P., Isaksen, I., Iversen, I., Kloster, S., Koch, D., Kirkevåg, A., Kristjansson, J. E., Krol, M., Lauer, A., Lamarque, J. F., Liu, X., Montanaro, V., Myhre, G., Penner, J., Pitari, G., Reddy, S., Seland, Ø., Stier, P., Takemura, T., and Tie, X.: Analysis and quantification of the diversities of aerosol life cycles within AeroCom, Atmos. Chem. Phys., 6, 1777-1813, 2006,

http://www.atmos-chem-phys.net/6/1777/2006/.

Textor, C., Schulz, M., Guibert, S., Kinne, S., Balkanski, Y., Bauer, S., Berntsen, T., Berglen, T., Boucher, O., Chin, M., Dentener, F., Diehl, T., Feichter, J., Fillmore, D., Ginoux, P., Gong, S., Grini, A., Hendricks, J., Horowitz, L., Huang, P., Isaksen, I. S. A., Iversen, T., Kloster, S., Koch, D., Kirkevåg, A., Kristjansson, J. E., Krol, M., Lauer, A., Lamarque, J. F., Liu, X., Montanaro, V., Myhre, G., Penner, J. E., Pitari, G., Reddy, M. S., Seland, Ø., Stier, P., Takemura, T., and Tie, X.: The effect of harmonized emissions on aerosol properties in global models - an AeroCom experiment, Atmos. Chem. Phys., 7, 4489-4501, 2007, http://www.atmos-chem-phys.net/7/4489/2007/.

The GFDL Global Atmospheric Model Development Team: The new GFDL global atmosphere and land model AM2-LM2: Evaluation with prescribed SST simulations, J. Climate, 17, 46414673, 2004.
Thomas, G. E., Poulsen, C. A., Sayer, A. M., Marsh, S. H., Dean, S. M., Carboni, E., Siddans, R., Grainger, R. G., and Lawrence, B. N.: The ORAC ATSR-2 aerosol retrieval algorithm for GRAPE, AMT, 2, 679-701, 2009.

Tian, B., Waliser, D. E., Kahn, R. A., Li, Q., Yung, Y. L., Tyranowski, T., Geogdzhayev, I. V., Mishchenko, M. I., Torres, O., and Smirnov, A.: Does the Madden-Julian Oscillation influence aerosol variability?, J. Geophys. Res., 113, D12215, doi:10.1029/2007JD009372, 2008.

Tie, X. X., Madronich, S., Walters, S., Edwards, D. P., Ginoux, P., Mahowald, N., Zhang, R. Y., Lou, C., and Brasseur, G.: Assessment of the global impact of aerosols on tropospheric oxidants, J. Geophys. Res., 110, D03204, doi:10.1029/2004JD005359, 2005.

Tiedtke, M.: Representation of clouds in large-scale models, Mon. Weather Rev., 212, 3040-3061, 1993.

Twohy, C. H., Coakley Jr, J. A., and Tahnk, W. R.: Effect of changes in relative humidity on aerosol scattering near clouds, J. Geophys. Res., 114, D05205, doi:10.1029/2008JD010991, 2009.

Twomey, S.: Pollution and the planetary albedo, Atmos. Environ., 8, 1251-1256, 1974.

Várnai, T. and Marshak, A.: MODIS observations of enhanced clear-sky reflectance near clouds, Geophys. Res. Lett., 36, L06807, doi:10.1029/2008GL037089, 2009.

Wen, G., Marshak, A., Cahalan, R. F., Remer, L. A., and Kleidman, R. G.: 3-D aerosol-cloud radiative interaction observed in collocated MODIS and ASTER images of cumulus cloud fields, J. Geophys. Res., 112, D13204, doi:10.1029/2006JD008267, 2007.

Wielicki, B. A.,Barkstrom, B. R., Harrison, E. F., Lee III, R. B., Smith, G. L., and Cooper, J. E.: Clouds and the Earth's Radiant Energy System (CERES): An earth observing system experiment, B. Am. Meteorol. Soc., 77, 853-868, 1996.

Wang, M. and Penner, J. E.: Aerosol indirect forcing in a global model with particle nucleation, Atmos. Chem. Phys., 9, 239-260, 2009 , http://www.atmos-chem-phys.net/9/239/2009/.

Wang, M. and Penner, J. E.: Cirrus clouds in a global climate model with a statistical cirrus cloud scheme, Atmos. Chem. Phys. Discuss., 9, 16607-16682, 2009,

http://www.atmos-chem-phys-discuss.net/9/16607/2009/.

Wang, M., Penner, J. E., and Liu, .: Coupled IMPACT aerosol and NCAR CAM3 model: Evaluation of predicted aerosol number and size distribution, J. Geophys. Res., 114, D06302, doi:10.1029/2008JD010459, 2009.

Wood, R.: Cancellation of aerosol indirect effects in marine stratocumulus through cloud thinning, J. Atmos. Sci., 64, 26572669, 2007.

Zhang, J., Reid, J. S., and Holben, B. N.: An analysis of potential cloud artifacts in MODIS over ocean aerosol optical thickness products, Geophys. Res. Lett., 32, L15803, doi:10.1029/2005GL023254, 2005.

Zhang, M., Lin, W., Bretherton, C. B., Hack, J. J., and Rasch, P. $\mathrm{J}$.: A modified formulation of fractional stratiform condensation rate in the NCAR Community Atmosphere Model (CAM2), J. Geophys. Res., 108, 4035, doi:10.1029/2002JD002523, 2003. 